\title{
Is the toxic potential of nanosilver dependent on its size?
}

Anna Huk ${ }^{1,2}$, Emilia Izak-Nau²,3, Bogumila Reidy ${ }^{4}$, Matthew Boyles², Albert Duschl', Iseult Lynch ${ }^{5}$ and Maria Dušinska ${ }^{1 *}$

\begin{abstract}
Background: Nanosilver is one of the most commonly used engineered nanomaterials (ENMs). In our study we focused on assessing the size-dependence of the toxicity of nanosilver (Ag ENMs), utilising materials of three sizes (50, 80 and $200 \mathrm{~nm}$ ) synthesized by the same method, with the same chemical composition, charge and coating.

Methods: Uptake and localisation (by Transmission Electron Microscopy), cell proliferation (Relative growth activity) and cytotoxic effects (Plating efficiency), inflammatory response (induction of IL-8 and MCP-1 by Enzyme linked immune sorbent assay), DNA damage (strand breaks and oxidised DNA lesions by the Comet assay) were all assessed in human lung carcinoma epithelial cells (A549), and the mutagenic potential of ENMs (Mammalian hprt gene mutation test) was assessed in V79-4 cells as per the OECD protocol. Detailed physico-chemical characterization of the ENMs was performed in water and in biological media as a prerequisite to assessment of their impacts on cells. To study the relationship between the surface area of the ENMs and the number of ENMs with the biological response observed, Ag ENMs concentrations were recalculated from $\mu \mathrm{g} / \mathrm{cm}^{2}$ to ENMs $\mathrm{cm}^{2} / \mathrm{cm}^{2}$ and ENMs $/ \mathrm{cm}^{2}$.

Results: Studied Ag ENMs are cytotoxic and cytostatic, and induced strand breaks, DNA oxidation, inflammation and gene mutations. Results expressed in mass unit $\left[\mu \mathrm{g} / \mathrm{cm}^{2}\right]$ suggested that the toxicity of Ag ENMs is size dependent with $50 \mathrm{~nm}$ being most toxic. However, re-calculation of Ag ENMs concentrations from mass unit to surface area and number of ENMs per $\mathrm{cm}^{2}$ highlighted that $200 \mathrm{~nm} \mathrm{Ag}$ ENMs, are the most toxic. Results from hprt gene mutation assay showed that Ag ENMs $200 \mathrm{~nm}$ are the most mutagenic irrespective of the concentration unit expressed.
\end{abstract}

Conclusion: We found that the toxicity of Ag ENMs is not always size dependent. Strong cytotoxic and genotoxic effects were observed in cells exposed to Ag ENMs 50 nm, but Ag ENMs $200 \mathrm{~nm}$ had the most mutagenic potential. Additionally, we showed that expression of concentrations of ENMs in mass units is not representative. Number of ENMs or surface area of ENMs $\left(\right.$ per $\mathrm{cm}^{2}$ ) seem more precise units with which to compare the toxicity of different ENMs.

Keywords: Size-related nanomaterial toxicity, Silver nanomaterials, Uptake and localisation, Cytotoxicity, Inflammation, DNA damage, Mutagenicity

\section{Background}

Nanosilver is one of the most commonly used engineered nanomaterials (ENMs), and because of its unique physico-chemical properties and antibacterial potential it plays an important role in many industries, including food packaging, textiles production, agriculture and water disinfection [1-5]. Nevertheless, the commercially most

\footnotetext{
* Correspondence: maria.dusinska@nilu.no

'Department of Environmental Chemistry, Health Effects Laboratory, NILU, Instituttveien 18, 2007 Kjeller, Norway

Full list of author information is available at the end of the article
}

important applications are in medicine where it is used in bioimaging, biosensors, dental products, implants and wound dressings [6-8]. Medical products with nanosilver (Ag ENMs) were registered more than 60 years ago, however, the toxic potential of this ENM is still not well understood with significant debate as to whether the toxicity is entirely related to the dissolved ion fraction or can result from the nanoform also [9]. The first toxicology studies have reported controversial results. It has been shown that Ag ENMs can induce oxidative stress in 
human liver cells, DNA damage in testicular cells, human fibroblasts and peripheral blood cells, including DNA oxidation in human kidney cells and apoptosis in HeLa and human liver cells [10-15]. In other studies, Ag ENMs did not cause toxic effects in bone marrow cells, erythrocytes or human keratinocytes [16,17]. These discrepancies in toxicology studies may be explained by cell-type specific responses or coupled with the huge differences in the properties of the Ag ENMs used [18]. One of the main reasons for discrepancies between results in nanotoxicology studies in vitro is the lack of characterization of ENMs, especially under the actual exposure conditions in the relevant culture media. This includes also a lack of information about biological and chemical contamination of ENMs in the samples, and differences in experimental conditions such as in amount of protein in the cell culture media and whether the serum was heat inactivated or not [19-23]. In addition, a large part of these discrepancies is likely due to the fact that the ionic form $\left(\mathrm{Ag}^{+}\right)$is often present in an stock solutions in parallel to nanoforms due to its high dissolution potential [24]. The presence of $\mathrm{Ag}$ ions in the Ag ENM stocks can vary depending on ENMs preparation protocol or storage conditions [Izak-Nau E, Huk A, Reidy B, Uggerud H, Vadset $M$, Eiden S, Voetz $M$, Duschl A, Dušinska $M$, Lynch I: Impact of Storage Conditions and Storage Time on Silver Nanoparticle Physicochemcial Properties and Implications for Biological Effects. Manuscript in preparation].

The aim of the present study is a nanotoxicology evaluation of high-quality stable Ag ENMs, with 3 different sizes (50, 80 and $200 \mathrm{~nm}$ ), coated by polyvinylpyrrolidone (PVP) [25], prepared to ensure absence of Ag ions. Detailed characterization of the ENMs was performed to measure parameters which may influence the uptake of ENMs by cells and the biological response.

Toxic effects of Ag ENMs on lung cells were investigated previously [26-28]. However, no study has investigated the mutagenic effect of Ag ENMs using the Mammalian hprt gene mutation assay. Most studies on size dependent toxicity expressed the ENM concentration in mass units. In our research, Ag ENM concentrations were additionally re-calculated from mass units $\left[\mu \mathrm{g} / \mathrm{cm}^{2}\right]$ to surface area of ENMs $\left[\right.$ ENMs $\left.\mathrm{cm}^{2} / \mathrm{cm}^{2}\right]$ and number of ENMs [ENMs $/ \mathrm{cm}^{2}$ ] as for nanoforms these units are suggested to be more relevant concentration descriptors.

A large number of consumer products which can generate aerosolised Ag are already on the market including haircare products, antibacterial sprays, or air conditioning cleaning products. Ag in aerosol form can reach the human body by different routes; one of the main routes is inhalation where the principle targets are lung cells, which is the biological in vitro model considered in our study.

A human type II alveolar epithelial lung cell line (A549) was selected, since it is a common model for toxicity studies representing the lung, the major target organ for ENM accumulation by inhalation exposure [29]. Additionally, for the mutation study of ENM, we used the hprt gene mutation assay on Chinese hamster lung fibroblast cells (V79-4), according to the test guideline OECD 476 [30,31].

All used materials were synthesized by the same method, with minimum differences between batches, fully characterized by standard techniques: ENM size distribution and aggregation/agglomeration by dynamic light scattering (DLS), transmission and scanning electron microscopy (TEM and SEM) and analytical ultracentrifugation (AC); chemical composition by X-ray photoelectron spectroscopy (XPS), secondary ion mass spectroscopy and X-ray diffraction (XRD); surface composition by XPS and timeof-flight secondary ion mass spectrometry IV (ToF-SIMS); surface charge by zeta potential and specific surface area by the Brunauer-Emmett-Teller method (BET). For the toxicity studies, a range of different endpoints were addressed and standard methods have been applied: cell proliferation and cytotoxicity (Plating efficiency (PE) and Relative growth activity (RGA); genotoxicity (Comet assay); release of inflammatory markers (Enzyme-linked immunosorbent assay; ELISA) and mutagenicity (Mammalian in vitro hprt gene mutation tests, OECD 476). Uptake and subcellular localization of the ENMs was studied using TEM. Additionally, to study the relationship between surface area of ENMs and number of ENMs and the observed biological responses, all toxicology results were expressed as mass units, surface area of ENMs and number of ENMs $\left(\right.$ per $\left.\mathrm{cm}^{2}\right)$.

\section{Methods \\ Ag ENM synthesis}

To synthesize Ag ENMs, 1 g of Luvitec $\mathrm{K}^{\circ} 0^{\circ}$ (PVP) was dissolved in $50 \mathrm{ml}$ of $0.054 \mathrm{M} \mathrm{NaOH}$ aqueous solution. The reaction solution was poured directly into $0.054 \mathrm{M} \mathrm{AgNO}_{3}$ and stirred at $400 \mathrm{rpm}(50 \mathrm{~nm}$ : $\mathrm{t}=60 \mathrm{~min}, \mathrm{~T}=21^{\circ} \mathrm{C}, 80 \mathrm{~nm}: \mathrm{t}=60 \mathrm{~min}, \mathrm{~T}=60^{\circ} \mathrm{C}$, $200 \mathrm{~nm}: \mathrm{t}=30 \mathrm{~min}, \mathrm{~T}=80^{\circ} \mathrm{C}$ ). Ten $\mathrm{ml}$ of formaldehyde $37 \%$ aqueous solution (FA) was added to the reaction mixture with stirring for $1 \mathrm{~h}$ at RT.

After the reaction times the solutions were transferred onto ice for $1 \mathrm{~h}$. The ENM dispersions were centrifuged at $15000 \mathrm{rpm}(50 \mathrm{~nm}), 12000 \mathrm{rpm}$ $(80 \mathrm{~nm})$ and $8000 \mathrm{rpm}(200 \mathrm{~nm})$ for $20 \mathrm{~min}$. The ENMs were washed with acetone, and then with deionized water, to remove any unreacted FA and PVP. Subsequently, the ENM dispersions were sonicated with a $5 \mathrm{~mm}$ microtip for $5 \mathrm{~min}$ at 30\% amplitude 
(Sonikator-Digital Sonifer ${ }^{\circledR} 450$; Branson Ultrasonics Corporation). The concentration of the ENMs was determined to be $1 \%$ using a Halogen Moisture Analyzer (Mettler Toledo, HR73).

\section{Cell lines}

Human lung carcinoma epithelial cells (A549) were cultured in flasks in RPMI 1640 media (Sigma) with 10\% heat inactivated foetal bovine serum (FBS; Sigma), 1\% penicillin - streptomycin (Sigma) in a humidified atmosphere of $5 \% \mathrm{CO}_{2}$ and $37^{\circ} \mathrm{C}$. In each experiment cells of passages between 3-6 were used.

Chinese hamster lung fibroblast cells (V79-4) were cultured in flasks in DMEN low glucose media (Sigma), with activated $10 \%$ FBS, $1 \%$ penicillin-streptomycin and L-glutamine (Sigma) in a humidified atmosphere of $5 \% \mathrm{CO}_{2}$ at $37^{\circ} \mathrm{C}$.

\section{Physicochemical characterization}

The hydrodynamic size/size distribution and zeta potential of the pristine ENMs were measured using a Zetasizer $3000 \mathrm{HSa}$, Malvern Instruments. The ENMs size was assessed by DLS using a He-Ne laser (633 $\mathrm{nm}$ ) as the light source. The stock suspension was diluted with deionized water to result in a count rate of 100-500 kcps. ENM sizing measurements were performed in $10 \mathrm{~mm}$ polystyrene cuvettes at $25^{\circ} \mathrm{C}$. The results are given as $\mathrm{Z}$-average values of the number, volume and intensity size distributions. The zeta potential was determined by Laser Doppler Electrophoresis (LDE) using a quartz capillary electrophoresis cell. All measurements were performed in triplicate for a single batch of ENMs and the results were the average of the three measurements.

The ENM size distributions were additionally determined by AC using a Beckman Ultracentrifuge type XL70, equipped with an optical device. A diode laser (695 nm) with an optical fiber was used as the light source. It was operated at the constant voltage of $6 \mathrm{~V}$ using a T4N16B8 generator from Gossen. A $3 \mathrm{~mm}$ Beckman quartz cell was used as the ultracentrifuge cell with a gap width of about $0.3 \mathrm{~mm}$ for the passage of the light. The samples were diluted with deionized water to obtain concentrations ranging from $0.5-0.05 \%$. Depending on the ENM sizes, the samples were centrifuged for $10-120 \mathrm{~min}$ at speeds between 4000 and $50000 \mathrm{U} / \mathrm{min}$.

The primary ENM sizes and shapes were assessed using a Phillips CM20 TEM working at $200 \mathrm{keV}$. For TEM analysis, stock ENM suspensions were diluted 1:100 in deionized water and $3 \mu \mathrm{l}$ was pipetted onto holey carbon grids (S162, Plano $\mathrm{GmbH}$ ) and subsequently left to evaporate. Around 700 ENMs were selected to estimate ENMs size/size distribution using the analysis pro software.
The primary ENM sizes and shapes were additionally assessed using an FEI Sirion $100 \mathrm{~T}$ SEM working at $10 \mathrm{keV}$. For SEM analysis, $20 \mu \mathrm{l}$ stock suspensions were dried directly onto the carbon adhesive pad of an SEM sample holder.

The chemical and elemental composition of the ENMs were examined with a PHI VersaProbe 5000 $\mathrm{XPS}$, using a monochromated $\mathrm{Al} \mathrm{K} \alpha \mathrm{X}$-ray beam scanned over $600 \mu \mathrm{m} \times 400 \mu \mathrm{m}$ area $(200 \mu \mathrm{m}$ diameter/50 W $\mathrm{X}$-ray beam $)$ or $1400 \mu \mathrm{m} \times 100 \mu \mathrm{m}(100 \mu \mathrm{m}$ diameter/ $100 \mathrm{~W}$ X-ray beam) at a fixed take-off angle of $45^{\circ}$. For XPS analysis, the stock suspensions were dried onto an indium or silicon surface. Spectra evaluation of 10 total measuring cycles was performed using MultiPack-Version 9.2 software. The results in \% were derived from the relative concentrations of elements and their chemical bonds from line shape analysis.

Surface chemistry measurements were performed using a ToF-SIMS. The primary ion species used was $10 \mathrm{keV} \mathrm{Ga}^{+}$, scanning an area of typically $150 \times 150 \mu^{2}$. For SIMS analysis, the stock suspensions were dried onto a silicon surface.

Crystallite size and crystalline phase were evaluated by XRD using a PANalytical EMPYREAN PIXcel with $3 \mathrm{D}$ Counter, operating at a voltage of $40 \mathrm{kV}$ and a current of $40 \mathrm{~mA}$ with $\mathrm{Cu} K \alpha$ and $K \beta$ radiation. For XRD analysis, the stock suspensions were dried onto a silicon surface.

Specific surface area was determined using the BET method, from nitrogen adsorption/desorption isotherms, recorded at $77 \mathrm{~K}$ on a Gemini 2360 from Micromeritics S/N 3014. The measuring range was $0.1-1000 \mathrm{~m}^{2} / \mathrm{g}$. The stock solution was freeze dried to obtain $0.5 \mathrm{~g}$ of the examined sample. ENM concentration was additionally analyzed with a Halogen Moisture Analyzer (Mettler Toledo, HR73). One gram of the stock solution was placed onto the analyzer plate and left to allow solvent evaporation to give the wt/wt \% value.

To investigate the ENM stability in biological media, the ENM dispersions were prepared in DMEM or RPMI 1600 medium, supplemented with 10\% FBS. The ENMs were incubated for 2,24 and $48 \mathrm{~h}$ (relevant to the toxicological tests) at $37^{\circ} \mathrm{C}$ in a $\mathrm{CO}_{2}$ incubator. The ENM properties in the biological environment were characterized using DLS.

A previous study utilising these Ag ENMs assessed the kinetics of dissolution and found that even after 4 months of storage (in water, $t=5^{\circ} \mathrm{C}$ ) no significant changes in Ag ENMs physico-chemical properties, including dissolution, were observed [32]. While not explicitly assessed, no significant dissolution in cell culture media is expected over the timeframe of the studies, as a result of the PVP capping, which reduces 
dissolution [33] and reduces protein binding [34]. The ENMs were produced and handled under semi-sterile conditions, and no endotoxin contamination was found during random checking of ENMs (performed by Yang $\mathrm{Li}$, Nazionale delle Institute de la Ricerche, Pisa, Italy as part of the EU FP7 NanoTOES consortium) using the LAL assay (personal communication, and publication in preparation).

\section{Uptake and localisation of ENMs - transmission electron microscopy (TEM)}

A549 cells were grown on $35 \mathrm{~mm}$ Petri dishes, at a density which allowed them to reach $80 \%$ confluence at the end of the exposure period (2, 24 and $48 \mathrm{~h})$. $24 \mathrm{~h}$ after seeding, the cells were exposed to Ag ENMs $50 \mathrm{~nm}\left(5.3 \mu \mathrm{g} / \mathrm{cm}^{2}\right.$, $\left.2.7 \times 10^{11} \mathrm{ENMs} / \mathrm{cm}^{2}\right), 80 \mathrm{~nm}\left(5.3 \mu \mathrm{g} / \mathrm{cm}^{2}, 0.55 \times 10^{11}\right.$ ENMs $\left./ \mathrm{cm}^{2}\right)$ and $200 \mathrm{~nm}\left(10.5 \mu \mathrm{g} / \mathrm{cm}^{2}, 0.2 \times 10^{11}\right.$ ENMs/ $\mathrm{cm}^{2}$ ) for 2, 24 and $48 \mathrm{~h}$. After exposure, cells were fixed in $2.5 \%$ glutaraldehyde in $0.1 \mathrm{M}$ Sorensen phosphate buffer ( $\mathrm{pH}$ 7.3) for at least $1 \mathrm{~h}$. Afterwards, cells were washed with $0.1 \mathrm{M}$ Sorensen phosphate buffer (pH 7.3) and postfixed in $1 \%$ osmium tetroxide in deionised water for $1 \mathrm{~h}$. Samples were then dehydrated in increasing concentrations of ethanol (from $70 \%$ to $100 \%, 10-20$ min each step), immersed in ethanol/Epon (1:1 v/v) mixture and embedded in pure Epon $\left(2 \mathrm{~h}\right.$ in $\left.37^{\circ} \mathrm{C}\right)$ and polymerised for $24 \mathrm{~h}$ at $60^{\circ} \mathrm{C}$. Sections $(\sim 80 \mathrm{~nm})$ were cut using a diamond knife on an ultra-microtome Leica EM UC6 and mounted on copper grids. Before image acquisition, sections were stained using uranyl acetate and lead citrate. All images were acquired on an FEI TECNAI 120 TEM $(120 \mathrm{kV})$.

Proliferation assay - relative cell growth activity (RGA) A549 cells were seeded on 6 -well plates $\left(1.2 \times 10^{5}\right.$ cells per well) and incubated at $37^{\circ} \mathrm{C}$. After $24 \mathrm{~h}$, the cells were exposed to Ag ENMs (50, 80 or $200 \mathrm{~nm}$ ) for 2, 24 and $48 \mathrm{~h}$ at concentrations ranging from $1.1-21.1 \mu \mathrm{g} / \mathrm{cm}^{2}$. At the end of the exposure period, medium was removed; cells were washed with PBS, trypsinized and re-suspended in $1 \mathrm{ml}$ medium. $10 \mu \mathrm{l}$ of the cell suspension was mixed with $10 \mu \mathrm{l} 0.4 \%$ trypan blue (Invitrogen) and the percentages of living cells (unstained) and stained cells with damaged membranes were measured using a Countess ${ }^{\mathrm{Tm}}$ Automated Cell Counter (Invitrogen). Measurements were performed immediately upon staining (for all three exposure times).

RGA was calculated according to the following formula:

\section{Plating efficiency (PE)}

A549 cells were exposed to Ag ENMs, washed and counted as described above. 100 cells per well were inoculated in 6-well plates (1 plate for each ENM size/tested concentration) and left in an incubator at $37^{\circ} \mathrm{C}$ for 10 days. The cells were then stained with $1 \%$ methylene blue (Sigma) and the number of colonies was counted manually.

PE was calculated according to the follow formula:

$$
P E(\%)=\frac{\text { number of colonies in exposed cultures }}{\text { number of colonies in unexposed cultures }} \times 100 \%
$$

\section{Cell morphology}

To observe changes in cell morphology such as rounded, shrunken or detached cells, A549 cells were seeded in 6 -well cell culture plates at a density of $1.2 \times 10^{5}$ cells/ $\mathrm{ml}$. The next day, cells were treated with Ag ENMs $\left(21.2 \mu \mathrm{g} / \mathrm{cm}^{2}, 50,80\right.$ or $\left.200 \mathrm{~nm}\right)$ for $24 \mathrm{~h}$ and observed under an optical microscope (Leica, model DM-IL). Images were captured under $100 \times$ magnification using the microscope's camera (Motic, model Motican 3 software Motic Images 2.0 ML). Cell morphology was analysed visually by comparing about 90 images each of untreated and treated cells.

\section{Enzyme-linked immunosorbent assay (ELISA)}

The ELISA assay, for IL-8 and MCP-1, was used to assess the immune response of A549 cells exposed to Ag ENMs $(50,80$ or $200 \mathrm{~nm})$. A549 cells were seeded on 24-well plates $\left(0.25 \times 10^{5}\right.$ cells per well $)$ and incubated at $37^{\circ} \mathrm{C}$. Cells were exposed to Ag ENMs for $24 \mathrm{~h}$ at concentrations ranging from $0.21-15.6 \mu \mathrm{g} / \mathrm{cm}^{2}$. After exposure, supernatant was collected and centrifuged at $14000 \mathrm{rpm}$ for $5 \mathrm{~min}$. A 96 well plate was pre-coated with specific capture antibodies $(0.5 \mu \mathrm{g} / \mathrm{ml})$ (Peprotech; NJ, USA) and left overnight at $4{ }^{\circ} \mathrm{C}$. The following day the plate was washed 3 times (PBS, 0.05\% Tween) and $100 \mu \mathrm{l}$ blocking buffer (PBS, 1\% BSA) was added to each well and incubated for $2 \mathrm{~h}$ at room temperature in the dark and then the plate was washed again. Exposure medium, blank and protein standards (15.6-1000 pg/ml) were placed in wells and were incubated for $2 \mathrm{~h}$. The plate was then washed and incubated with detection antibodies $(0.5 \mu \mathrm{g} / \mathrm{ml})$ (Peprotech) for $1 \mathrm{~h}$, then washed again and incubated with avidin peroxidase conjugate for $30 \mathrm{~min}$. Again the plate was washed and 3,3,5,5 tetramethyl benzidine liquid substrate (Sigma) was added. The reaction was stopped using $2 \mathrm{M} \mathrm{H}_{2} \mathrm{SO}_{4}$ (Sigma). To

$$
R G A(\%)=\frac{(\text { number of living cells at day } n / \text { number of seeded cells at day } 0) \text { in exposed cultures }}{(\text { number of living cells at day } n / \text { number of seeded cells at day } 0) \text { in unexposed cultures }} \times 100 \%
$$


analyse the concentration of inflammatory markers present, the absorbance at $450 \mathrm{~nm}$ was measured using a Tecan Plate Reader. As a positive control, cells were treated with TNF $\alpha$ (20 ng/ml, $24 \mathrm{~h}$ ) (ImmunoTools; Friesoythe, Germany).

\section{The Comet assay}

The Comet assay was used to assess the genotoxicity of the Ag ENMs. Glass microscope slides were precoated with melted $0.5 \%$ normal melting point (NMP) agarose (Sigma) and let dry for at least $24 \mathrm{~h}$.

A549 cells were exposed to Ag ENMs, washed and counted as described above. After exposure of cells, medium was removed, cells were washed with PBS, trypsinized and re-suspended in $1 \mathrm{ml}$ of medium. Cell suspensions $\left(10^{4}\right.$ cells $)$ were re-suspended in $200 \mu \mathrm{l} 1 \%$ low melting point agarose (LMP, Sigma). $10 \mu \mathrm{l}$ of mixture was dropped onto pre-coated glass slides (2 drops per concentration, 12 drops per slide) and placed in the fridge for $10 \mathrm{~min}$. Slides were then put into lysis solution (2.5 M NaCl, 0.1 M EDTA, $10 \mathrm{mM}$ Tris, 10\% Triton $\mathrm{X}-100)$ [31]. After lysis, slides were subjected to alkaline solution (0.3 M NaOH, $1 \mathrm{mM}$ EDTA) for DNA unwinding, followed by electrophoresis at $25 \mathrm{~V}$ for $20 \mathrm{~min}$ in a standard Comet assay electrophoresis tank. Slides were then washed in PBS and subsequently in water and left overnight to dry. Slides were stained with SybrGold $(0.1 \mu \mathrm{l}$ of stock per $1 \mathrm{ml}$ of TE buffer - $10 \mathrm{mM}$ TrisHCl, $1 \mathrm{mM} \mathrm{Na}{ }_{2}$ EDTA, pH 7.5-8, Invitrogen), covered with a cover slip and examined by fluorescence microscopy (Leica DMI 6000 B). Images of comets were scored using image analysis Comet Assay IV software (Perspective Instruments), calculating the median of \% DNA in the tail from 50 comets per gel and the mean from 3 experiments.

For detection of oxidative DNA damage we used the modified version of the Comet assay with formamidopyrimidine DNA glycosylase (FPG). The FPG enzyme was kindly provided by Professor Andrew Collins (Department of Nutrition, University of Oslo, Norway). After lysis, the slides were washed with FPG buffer (40 mM HEPES, $0.1 \mathrm{M} \mathrm{KCl}, 0.5 \mathrm{mM}$ EDTA, $0.2 \mathrm{mg} / \mathrm{ml}$ bovine serum albumin, $\mathrm{pH}$ 8.0) and then incubated with FPG enzyme (30 $\mu \mathrm{l} /$ gel, $30 \mathrm{~min}, 37^{\circ} \mathrm{C}$ and a humidified atmosphere). Further steps were performed according to the standard Comet assay protocol described above. DNA oxidation lesions (NET FPG) were calculated as the difference between \% DNA in the tail in samples with FPG enzyme treatment and \% DNA in the tail in samples without FPG enzyme treatment. Positive controls were hydrogen peroxide (Sigma) (50 $\mu \mathrm{M}, 5 \mathrm{~min}$, on ice) for strand breaks (SBs) and the photosensitiser Ro19-8022 (Hoffman La Roche) plus visible light (1 $\mu \mathrm{M}$ in PBS, $5 \mathrm{~min}$, on ice) for DNA oxidation (NET FPG).
Mammalian in vitro hprt gene mutation test (OECD 476) V79-4 cells were seeded on 6 -well plates $\left(1 \times 10^{5}\right.$ cells per well) and incubated at $37^{\circ} \mathrm{C}$. After $24 \mathrm{~h}$, the cells were exposed to $\mathrm{Ag}$ ENMs (50, 80, $200 \mathrm{~nm}$ ) for $24 \mathrm{~h}$, at concentrations ranging from $0.21-15.6 \mu \mathrm{g} / \mathrm{cm}^{2}$. After exposure, the medium was removed, and cells were washed, trypsinized and re-suspended in $2 \mathrm{ml}$ medium. Cells were seeded in $\phi 100 \mathrm{~mm}$ Petri dishes $\left(3.5 \times 10^{5}\right.$ cells/Petri dish, 3 dishes per sample to achieve $10^{6}$ cells per sample), and cultivated in culture medium for an additional 8 days. Cells were harvested twice for mutations at days 6 and 8 after the treatment: cells were inoculated in $\phi 100 \mathrm{~mm}$ Petri dishes $\left(2 \times 10^{5}\right.$ cells/Petri dish, 5 dishes per sample to achieve $10^{6}$ cells per sample) and grown in selective medium containing 6-thioguanine (5 $\mathrm{\mu g} / \mathrm{ml}$, Sigma) for 10 days to form colonies. Mutant colonies were stained with $1 \%$ methylene blue and counted manually. Only colonies with a minimum of 50 cells were counted.

The number of surviving cells was assessed by $\mathrm{PE}$ assay. On days $0,6,8$ after the exposure, 100 cells were plated into 6-well plates (100 cells per well, 1 plate for each sample) and incubated at $37^{\circ} \mathrm{C}$ for 7 days to form colonies. Cells were stained with $1 \%$ methylene blue and colonies were counted manually. The viability of cells was determined at the time of each mutation harvest and calculated based on the number of colonies versus the number of inoculated cells.

Mutant frequency was calculated according to the formula:

$$
\begin{aligned}
\text { Mutant frequency } & \left(\times 10^{6}\right) \\
= & \frac{\text { number of mutant colonies }}{\text { number of surviving inoculated cells }}
\end{aligned}
$$

Methyl methanesulfonate (MMS; $0.03 \mathrm{mM} ; 30 \mathrm{~min}$ ) (Sigma) was used as the positive control.

\section{Statistical analysis}

Data are expressed as mean \pm SD of two-four independent experiments. Significant differences between untreated controls and treatment groups were calculated using oneway analysis of variance (ANOVA) and Tukey's posthoc tests. To estimate $\mathrm{IC}_{50}$ values, a nonlinear regression analysis was used to fit a four parametric logistic curve. Graph Pad Prism software, Microsoft ${ }^{\oplus}$ Excel and Daniels XL toolbox software were used.

\section{Results}

Synthesis and characterization

PVP-stabilized Ag ENMs were produced with the desired sizes $(50,80,200 \mathrm{~nm})$. The results of the ENM characterization in water (as synthesised) are summarized in Table 1. SEM and TEM images show a quasi-spherical 
Table 1 Physicochemical characteristics of pristine Ag ENMs

\begin{tabular}{|c|c|c|c|}
\hline Name & Ag ENMs $50 \mathrm{~nm}$ & Ag ENMs $80 \mathrm{~nm}$ & Ag ENMs $200 \mathrm{~nm}$ \\
\hline Shape & quasi spherical & quasi spherical & quasi spherical \\
\hline \multicolumn{4}{|l|}{ Concentration } \\
\hline [\% wt/wt] & 1 & 1 & 1 \\
\hline [ENMs/ml] & $3.91 \times 10^{13}$ & $1.03 \times 10^{13}$ & $1.94 \times 10^{12}$ \\
\hline Specific surface area $\left[\mathrm{m}^{2} / \mathrm{g}\right]$ & $1.37 \times 10^{1}$ & 7.56 & 3.87 \\
\hline \multirow{4}{*}{$\begin{array}{l}\text { Size/size distribution \& aggregation/ } \\
\text { agglomeration state }[\mathrm{nm}]\end{array}$} & DLS: $74.5 \pm 1.2$ & DLS: $101.3 \pm 1.5$ & DLS: $272.5 \pm 2.2$ \\
\hline & $\mathrm{PDI}=0.130$ & $\mathrm{PDI}=0.115$ & $\mathrm{PDI}=0.136$ \\
\hline & TEM: $d_{50}=55 ; d_{90}=62$ & TEM: $d_{50}=78 ; d_{90}=96$ & TEM: $d_{50}=168 ; d_{90}=255$ \\
\hline & AC: $d_{50}=43 ; d_{90}=78$ & AC: $d_{50}=77 ; d_{90}=100$ & AC: $d_{50}=150 ; d_{90}=380$ \\
\hline Crystal structure & cubic & cubic & cubic \\
\hline \multirow{4}{*}{ Surface Chemistry [Atom\%] } & XPS: & XPS: & XPS: \\
\hline & $\begin{array}{l}\text { C:48.6, Ag:25.6, } \\
\text { O:15.9, N:7.7, Na:2.2 } \\
\end{array}$ & $\begin{array}{l}\text { C:59.1, O:17.5, } \\
\text { Ag:15.9, N } 7.5 \\
\end{array}$ & $\begin{array}{l}\text { C:58.1, O:18.0, } \\
\text { Ag:15.4, N:7.5, Na:1.0 }\end{array}$ \\
\hline & SIMS: & SIMS: & SIMS: \\
\hline & $\mathrm{Ag}, \mathrm{Na}, \mathrm{K}, \mathrm{Ca}, \mathrm{C}_{x} \mathrm{H}_{\mathrm{y}} \mathrm{O}_{z}$ & $\mathrm{Ag}, \mathrm{Cl}, \mathrm{C}_{x} \mathrm{H}_{\mathrm{y}} \mathrm{O}_{\mathrm{z}}$ & $\mathrm{Ag}, \mathrm{Na}, \mathrm{K}, \mathrm{C}_{x} \mathrm{H}_{y} \mathrm{O}_{z}$ \\
\hline Surface charge [mV] & $-17.5 \pm 0.5$ & $-12.5 \pm 0.5$ & $-5.5 \pm 0.5$ \\
\hline$\overline{\mathrm{pH}}$ & 5.9 & 5.9 & 6.0 \\
\hline
\end{tabular}

shape and good monodispersity of the ENMs (Figure 1, Additional file 1: Figure S1, Additional file 2: Figure S2 and Additional file 3: Figure S3). The monodispersity was additionally proven by DLS (Table 1 ) and analytical centrifugation (AC) measurements (Additional files 1, 2 and 3). The XRD spectra show the crystalline nature of the Ag ENM. The presence of PVP immobilized onto the ENMs surface was indicated by XPS and SIMS analysis. XPS data also demonstrated that all surface atoms are in the $\mathrm{Ag}^{0}$ state, confirming the absence of Ag ions at this time point. (Additional file 1: Figure S1, Additional file 2: Figure S2 and Additional file 3: Figure S3).

The ENMs analyzed by DLS in biological medium supplemented with $10 \%$ FBS did not show significant changes in size distribution which confirmed that PVP prevents ENM agglomeration in protein rich media [34] and also prevents dissolution of the ENMs over the relevant timescales (48 h).

\section{Uptake and subcellular localisation of Ag ENMs of different sizes}

The uptake and subcellular localisation of the Ag ENMs was confirmed using TEM. Firstly, the images confirmed that ENMs of all three sizes tested were taken up by A549 cells and retained their particulate nature over the exposure duration of 48 hours (Figure 2). Ag ENMs $50 \mathrm{~nm}$ (Figure 2.1A) were rapidly taken up by cells, and after just $2 \mathrm{~h}$ of exposure the ENMs were found inside the cells in dark-coloured vesicles, presumably lysosomes. Some single ENMs were localised in vesicles, very close to the cell surface. Some of those vesicles can be interpreted as endocytotic, clathrin-coated vesicles, which indicates an active mechanism of Ag ENM uptake. After 24 and $48 \mathrm{~h}$ exposure, Ag ENMs $50 \mathrm{~nm}$ were observed to form larger clusters in lysosomes (Figure 2.1B,C). The Ag ENMs $50 \mathrm{~nm}$ were not observed to interact directly with mitochondria in any of the tens of images assessed, although in

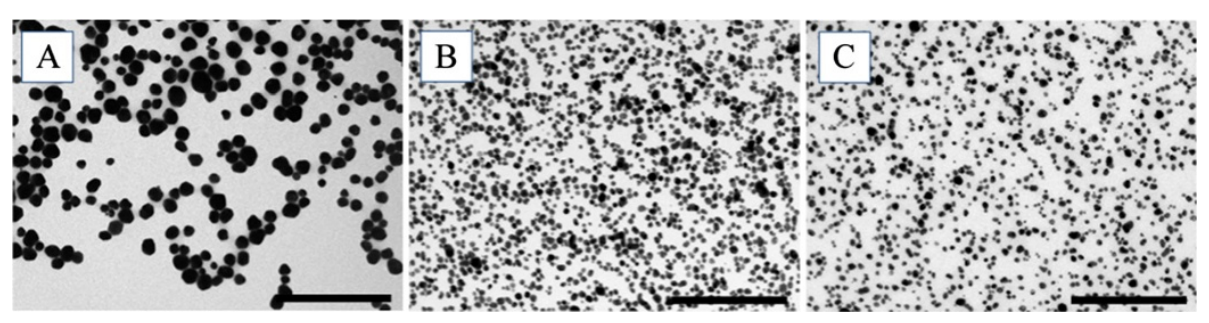

Figure 1 TEM characterization of pristine Ag ENMs: (A) Ag ENMs $200 \mathrm{~nm}$, (B) Ag ENMs $80 \mathrm{~nm}$, (C) Ag ENMs $50 \mathrm{~nm}$; scale bar: $1 \mu \mathrm{m}$. 


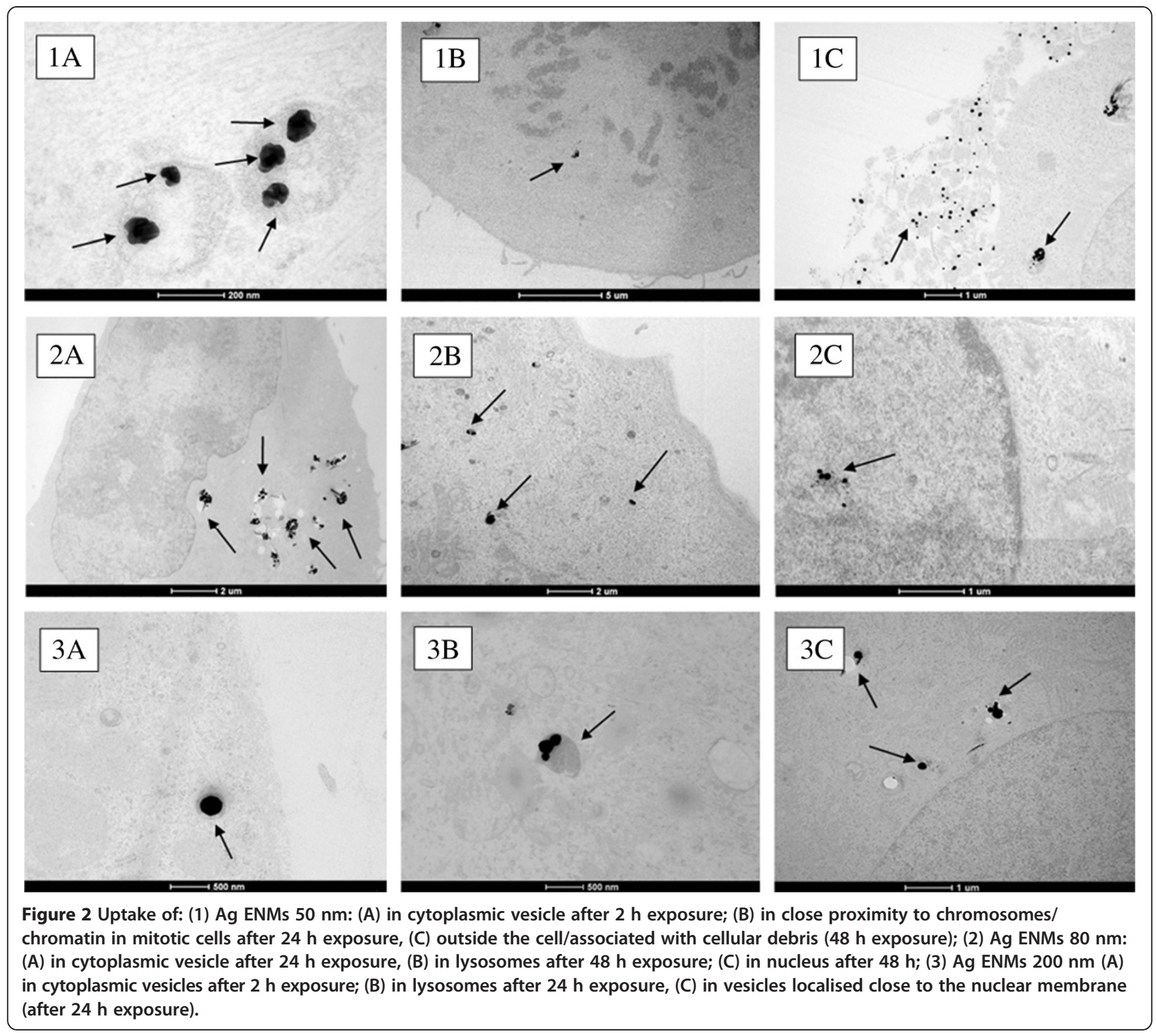

some cases vesicles containing Ag ENMs $50 \mathrm{~nm}$ were found in close proximity to those organelles. Ag ENMs $50 \mathrm{~nm}$ were not found inside the nucleus, although in the case of mitotic cells, where the nuclear membrane was disintegrated, they were found close to the chromosomes/ chromatin. Ag ENMs $80 \mathrm{~nm}$ (Figure 2.2A) were also found in lysosomes after $2 \mathrm{~h}$ of exposure, although many ENMs (more than in the case of Ag ENMs $50 \mathrm{~nm}$ ) were found in small, presumably endocytic vesicles. After $24 \mathrm{~h}$ exposure, a large number of Ag ENMs $80 \mathrm{~nm}$ was observed in lysosomes, where they formed big clusters. After $48 \mathrm{~h}$, most ENMs were located in lysosomes, although in one case ENMs were observed within the nucleus. A smaller quantity of Ag ENMs $200 \mathrm{~nm}$ were observed inside the cells compared to cells treated with Ag ENMs 50 and $80 \mathrm{~nm}$, consistent with literature for other ENMs but also likely related to the lower numbers of ENMs exposed at constant mass. After $2 \mathrm{~h}$ of exposure, Ag ENMs $200 \mathrm{~nm}$ were found in cytoplasmic vesicles or on the cell surface. After 24 h (Figures 2.3B,C) exposure, Ag ENMs $200 \mathrm{~nm}$ were found in cytoplasmic vesicles. No direct interactions with other organelles were observed. However, some vesicles containing ENMs were found close to the nuclear membrane. After $48 \mathrm{~h}$, much fewer ENMs $200 \mathrm{~nm}$ were found inside the cells compared to the smaller sized ENMs. ENMs were still localised mainly in cytoplasmic vesicles (not shown).

Effect of Ag ENM size on cytotoxicity and cell proliferation The effect of Ag ENMs with 3 different sizes and varying concentrations on cellular toxicity and proliferation was examined after 2, 24, $48 \mathrm{~h}$ exposure using PE and RGA. Data are presented with respect to the control cells that had no Ag ENM treatment (negative control). A clear 
concentration response was observed for all tested ENMs. On a mass basis, Ag ENMs $50 \mathrm{~nm}$ were considered the most cytotoxic of the tested materials (Figure 3), already evident during the $2 \mathrm{~h}$ exposure period in both PE and RGA tests. Conversely, expressing the data as ENMs $/ \mathrm{cm}^{2}$ or ENMs $\mathrm{cm}^{2} / \mathrm{cm}^{2}$, we observed the reverse trend, where from the three tested materials, Ag ENMs $200 \mathrm{~nm}$ gave the highest toxic response in A549 cells (Additional file 4: Figures S5 and S6). To highlight this ambiguity in dosimetry, an $\mathrm{IC}_{50}$ was calculated for each system, and is summarized in Table 2. There were no statistically significant differences between $\mathrm{IC}_{50}$ values calculated in mass units $\left[\mu \mathrm{g} / \mathrm{cm}^{2}\right]$. However, $\mathrm{IC}_{50}$ values (RGA) expressed as number of ENMs [ENMs*10 $10^{11} / \mathrm{cm}^{2}$ ] or surface area of ENMs [ENMs $\mathrm{cm}^{2} / \mathrm{cm}^{2}$ ] were found to be several-fold less for Ag ENMs $200 \mathrm{~nm}$ compared with Ag ENMs 50 and $80 \mathrm{~nm}$. Thus, a smaller number of the larger Ag ENMs can induce 50\% impedance of cell proliferation compared with ENMs with sizes 50 and $80 \mathrm{~nm}$.

\section{Observation of cellular morphology}

Morphological changes of A549 cells exposed to 50, 80, $200 \mathrm{~nm}$ Ag ENMs were observed using an inverted optical microscope (Additional file 4: Figure S4). After 24 h incubation with all three sizes of Ag ENMs, no changes of cellular morphology were observed, compared to the untreated cells (negative control). Detached or rounded cells were not observed. However, Ag ENMs attached to the cells can be observed as dark spots on the cell surface.

\section{Release of inflammation-related proteins}

The effect of 50, 80 and $200 \mathrm{~nm} \mathrm{Ag} \mathrm{ENMs} \mathrm{in} \mathrm{the} \mathrm{con-}$ centration range from $0.21-15.6 \mu \mathrm{g} / \mathrm{cm}^{2}$ on the cellular

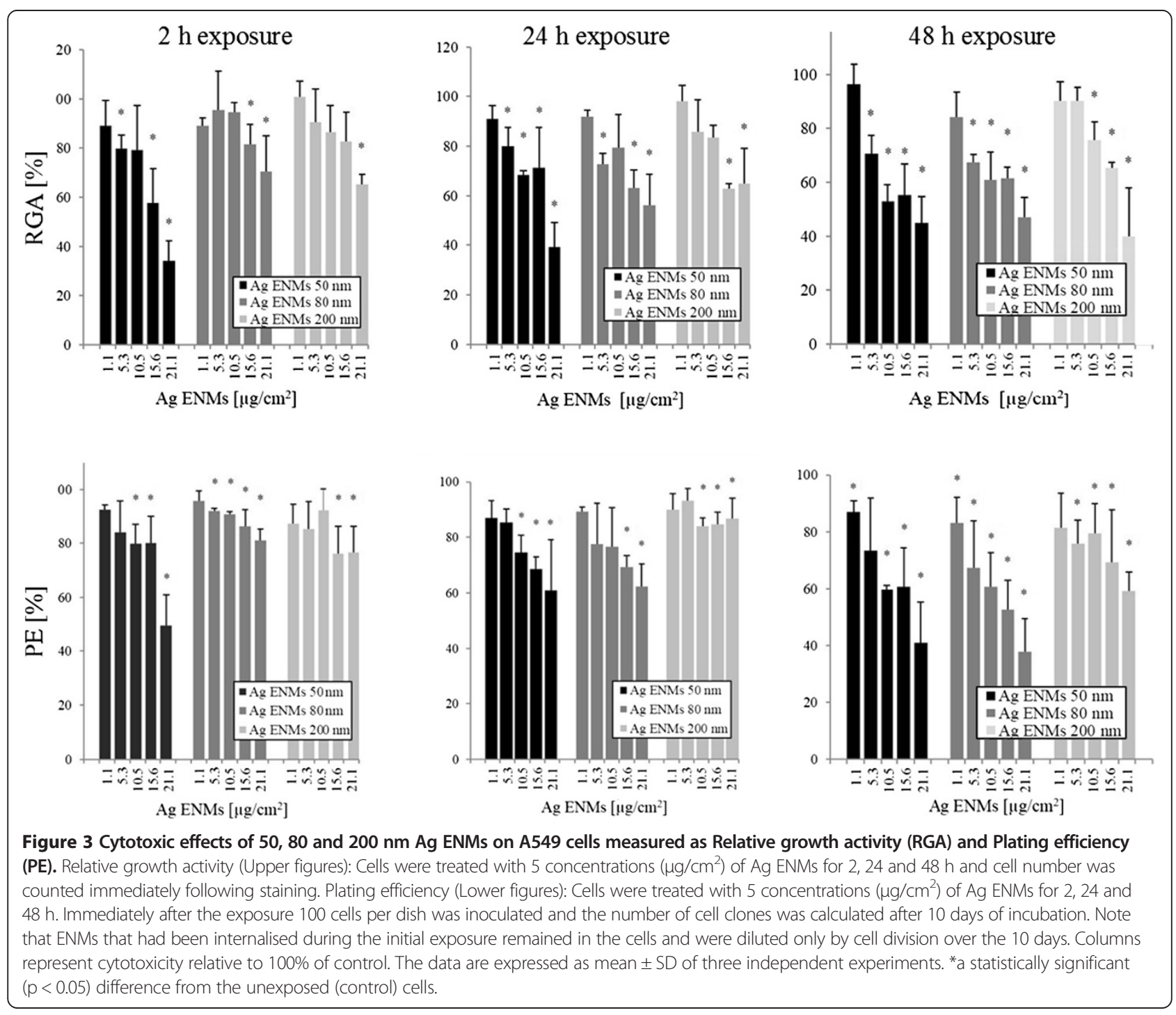


Table $2 \mathrm{IC}_{50}$ values related to exposure to $\mathrm{Ag}$ ENMs for Relative growth activity (RGA) and Plating efficiency (PE) assays in A549 cells (Time of exposure 2, 24, $48 \mathrm{~h}$ )

\begin{tabular}{|c|c|c|c|c|}
\hline & & $\begin{array}{l}\text { Ag ENMs } \\
50 \mathrm{~nm}\end{array}$ & $\begin{array}{l}\text { Ag ENMs } \\
80 \mathrm{~nm}\end{array}$ & $\begin{array}{l}\text { Ag ENM } \\
200 \mathrm{~nm}\end{array}$ \\
\hline \multicolumn{5}{|l|}{$\begin{array}{l}\text { Relative growth } \\
\text { activity }\end{array}$} \\
\hline \multirow[t]{3}{*}[\mu\mathrm{g}/\mathrm{cm}^{2}]{} & $\mathrm{T}=2 \mathrm{~h}$ & $16.8 \pm 1.71$ & $24.42 \pm 1.82$ & $23.68 \pm 1.51$ \\
\hline & $\mathrm{T}=24 \mathrm{~h}$ & $23.68 \pm 11.42$ & $37.53 \pm 17.58$ & $36.37 \pm 12.84$ \\
\hline & $\mathrm{T}=48 \mathrm{~h}$ & $15.94 \pm 1.33$ & $26.09 \pm 11.63$ & $21.71 \pm 7.41$ \\
\hline \multirow[t]{3}{*}[ENMs\times10^{11}/\mathrm{cm}^{2}]{} & $\mathrm{T}=2 \mathrm{~h}$ & $6.57 \pm 0.6$ & $2.51 \pm 0.19$ & $0.46 \pm 0.03$ \\
\hline & $\mathrm{T}=24 \mathrm{~h}$ & $9.26 \pm 4.47$ & $3.86 \pm 1.81$ & $0.75 \pm 0.25$ \\
\hline & $\mathrm{T}=48 \mathrm{~h}$ & $6.23 \pm 0.52$ & $2.69 \pm 1.2$ & $0.42 \pm 0.14$ \\
\hline \multirow[t]{3}{*}{ [ENMs $\left.\mathrm{cm}^{2} / \mathrm{cm}^{2}\right]$} & $\mathrm{T}=2 \mathrm{~h}$ & $2.3 \pm 0.23$ & $1.85 \pm 0.13$ & $0.61 \pm 0.53$ \\
\hline & $\mathrm{T}=24 \mathrm{~h}$ & $3.24 \pm 1.33$ & $2.84 \pm 1.33$ & $1.41 \pm 0.5$ \\
\hline & $\mathrm{T}=48 \mathrm{~h}$ & $2.18 \pm 0.18$ & $1.97 \pm 0.88$ & $0.84 \pm 0.29$ \\
\hline \multicolumn{5}{|l|}{ Plating efficiency } \\
\hline \multirow[t]{3}{*}[\mu\mathrm{g}/\mathrm{cm}^{2}]{} & $\mathrm{T}=2 \mathrm{~h}$ & $35.58 \pm 13.7$ & - & - \\
\hline & $\mathrm{T}=24 \mathrm{~h}$ & $31.65 \pm 15.81$ & $31.65 \pm 15.81$ & - \\
\hline & $\mathrm{T}=48 \mathrm{~h}$ & $17.83 \pm 4.5$ & $14.25 \pm 1.94$ & - \\
\hline \multirow[t]{3}{*}[ENMs\times10^{11}/\mathrm{cm}^{2}]{} & $\mathrm{T}=2 \mathrm{~h}$ & $13.91 \pm 5.35$ & - & - \\
\hline & $\mathrm{T}=24 \mathrm{~h}$ & $12.37 \pm 6.18$ & $3.66 \pm 0.41$ & - \\
\hline & $\mathrm{T}=48 \mathrm{~h}$ & $6.97 \pm 1.77$ & $1.48 \pm 0.2$ & - \\
\hline \multirow[t]{3}{*}{ [ENMs $\left.\mathrm{cm}^{2} / \mathrm{cm}^{2}\right]$} & $\mathrm{T}=2 \mathrm{~h}$ & $4.87 \pm 1.89$ & - & - \\
\hline & $\mathrm{T}=24 \mathrm{~h}$ & $4.37 \pm 2.17$ & $2.69 \pm 0.3$ & - \\
\hline & $\mathrm{T}=48 \mathrm{~h}$ & $2.44 \pm 0.62$ & $1.08 \pm 0.15$ & - \\
\hline
\end{tabular}

$-\mathrm{IC}_{50}$ could not be estimated. $\mathrm{IC}_{50}$ values were calculated for 3 different concentration characterization units: number of ENMs $\left(E N M s \times 10^{11} / \mathrm{cm}^{2}\right)$, surface area of ENMs $\left(E N M s \mathrm{~cm}^{2} / \mathrm{cm}^{2}\right)$ and mass of ENMs $\left(\mu \mathrm{g} / \mathrm{cm}^{2}\right)$ per exposure surface. production of inflammatory cytokines (IL-8 and MCP-1) by A549 cells was measured using the ELISA assay (Figure 4). Reverse concentration response trends were observed for all tested materials. However, statistically significant differences were not found between any of the tested Ag ENMs when plotted in mass units.

\section{Detection of DNA strand breaks and oxidised lesions}

The standard alkaline Comet assay was employed for detection of single and double strand breaks, and a modified version with FPG was used to detect oxidized DNA lesions (Figure 5). A significant concentration response was observed at all time points and for all ENMs tested. The strongest effect was observed in cells treated with $50 \mathrm{~nm} \mathrm{Ag}$ ENMs at all tested concentrations, and our data demonstrated that the genotoxic potential of Ag ENMs is both concentration and size dependent. No statistically significant difference was found between the level of DNA damage induced by Ag ENMs 80 and $200 \mathrm{~nm}$ at any exposure time (Figure 5A and B or Figure 5C and D). An increased level of oxidised DNA lesions was also observed in all treated groups (Figure $5 \mathrm{C}$ and D), but again the strongest effect was demonstrated in cells exposed to the smallest ENMs at the shortest exposure time. A significant level of DNA oxidation was already seen in cells exposed at the lowest concentration $\left(1.1 \mu \mathrm{g} / \mathrm{cm}^{2}\right)$ of Ag ENM $50 \mathrm{~nm}$. The high genotoxic response to ENMs $50 \mathrm{~nm}$ can be coupled with the higher number of ENMs compared to the number of $80 \mathrm{~nm}$ and $200 \mathrm{~nm}$ ENMs. Re-calculating the data from mass units $\left[\mu \mathrm{g} / \mathrm{cm}^{2}\right]$ to number of ENMs [ENMs* $10^{11} / \mathrm{cm}^{2}$ ] or surface area of ENMs [ENMs $\mathrm{cm}^{2} / \mathrm{cm}^{2}$ ] showed that Ag $50 \mathrm{~nm}$ ENMs

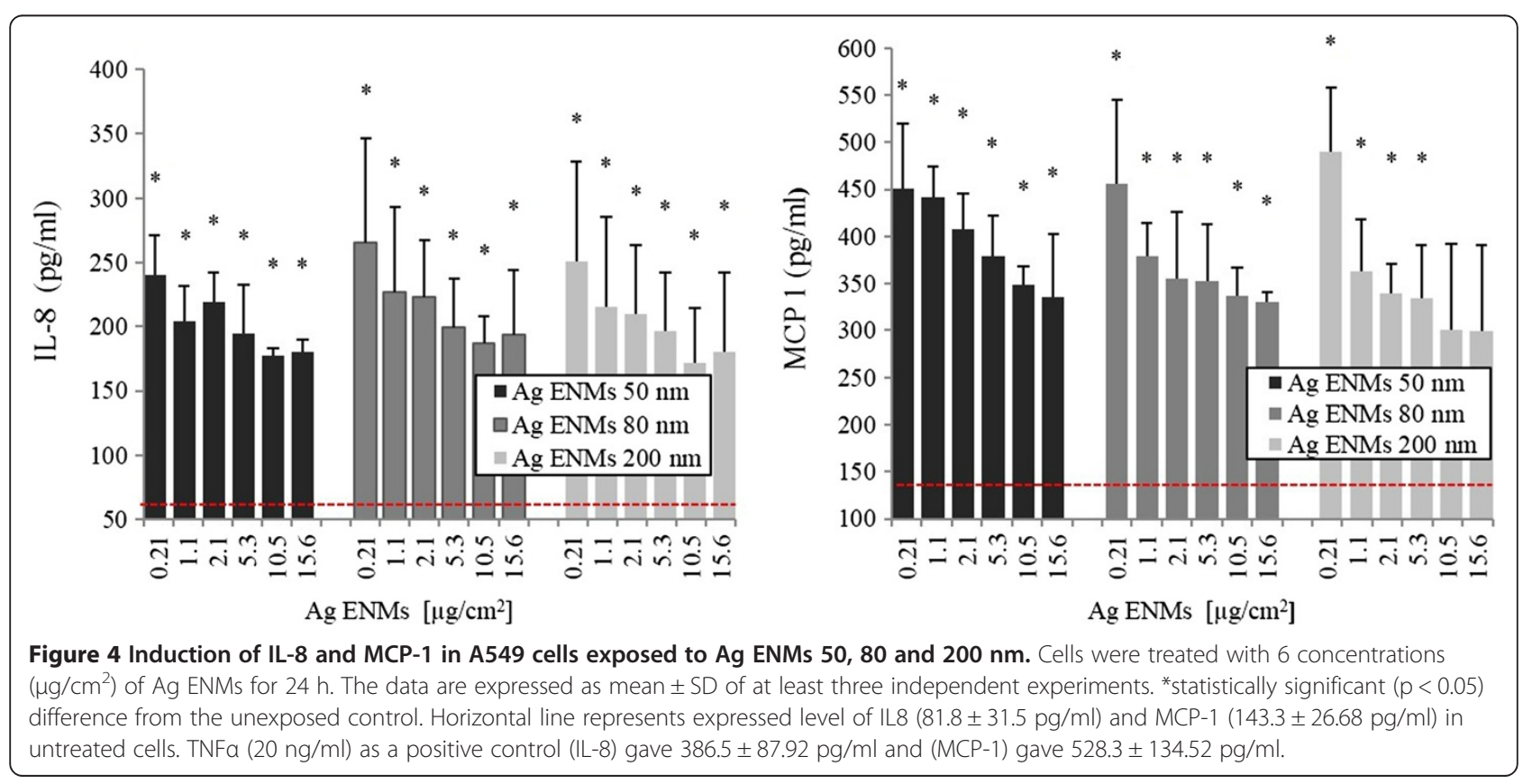




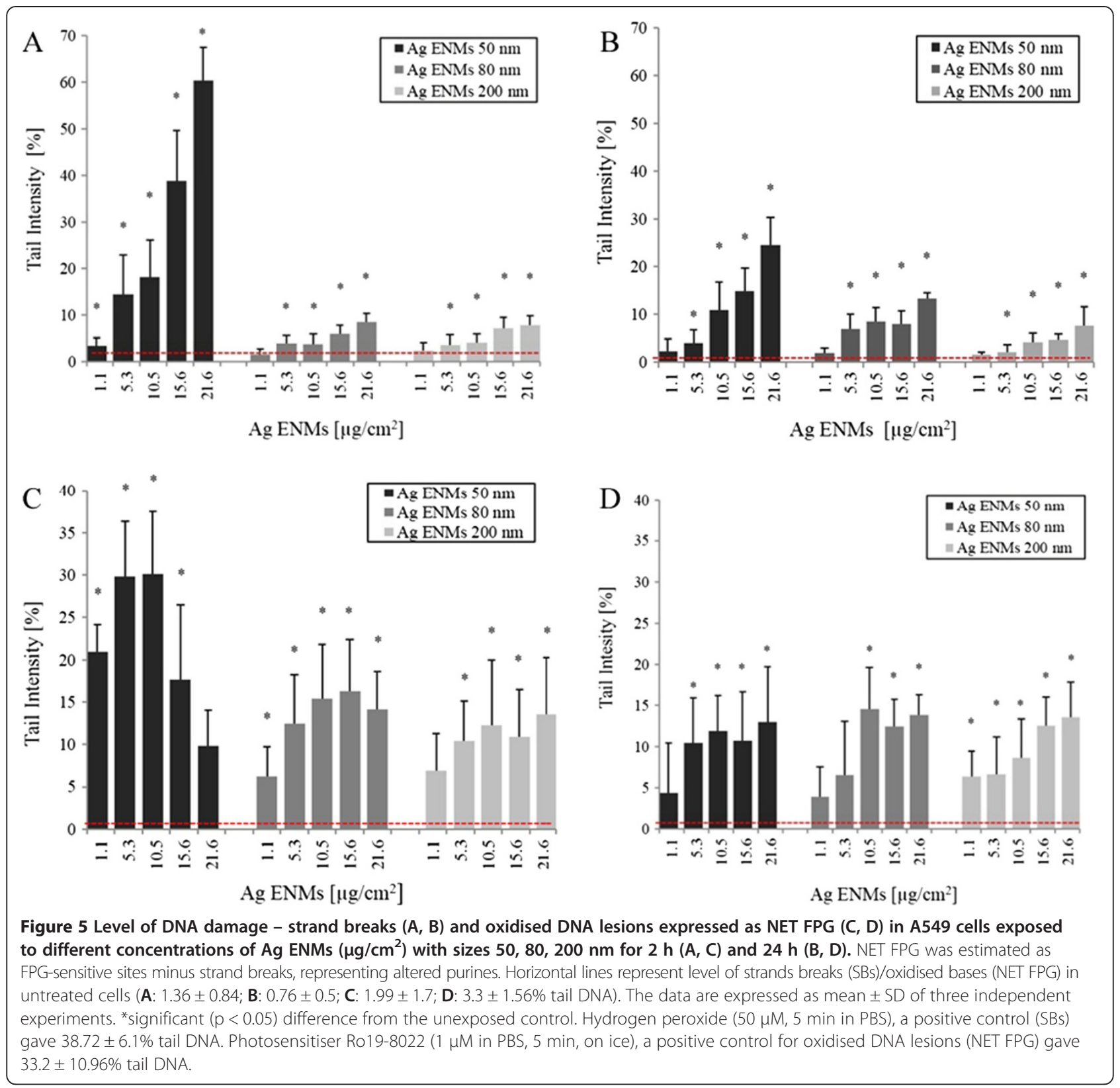

are the most genotoxic only at short time exposures $-2 \mathrm{~h}$, but for longer treatment times the highest DNA damaging effect was observed with $200 \mathrm{~nm}$ Ag ENMs. Supplementary figure (Additional file 4: Figure S7 and S8).

\section{Impact of Ag ENMs on induction of gene mutations}

The mutagenic potential of 50, 80, $200 \mathrm{~nm}$ Ag ENMs was examined using the hprt gene mutation assay according to OECD guideline 476. Two independent experiments, each with two mutation harvests, were performed (Figure 6A). Ag ENM $200 \mathrm{~nm}$ were observed to be the most mutagenic $(\mathrm{p}<0.001)$, at all concentrations tested. The data are presented in mass units; however, this pattern holds true when plotted as number of ENMs, or by surface area. We observed the highest frequency of hprt mutants in the first experiment; mutant frequency was $9.6 \pm 5.25$ times higher than the negative control. The frequency of induced mutants in several groups was comparable with the mutant frequency found with the positive control (MMS). For cells treated with Ag ENMs 50 and $80 \mathrm{~nm}$ there was a trend towards higher mutant frequency of $80 \mathrm{~nm}$ ENMs compared with $50 \mathrm{~nm}$; however, this was not significant.

\section{Discussion}

The increasing number of consumer products containing Ag ENMs stimulates researchers to investigate their 


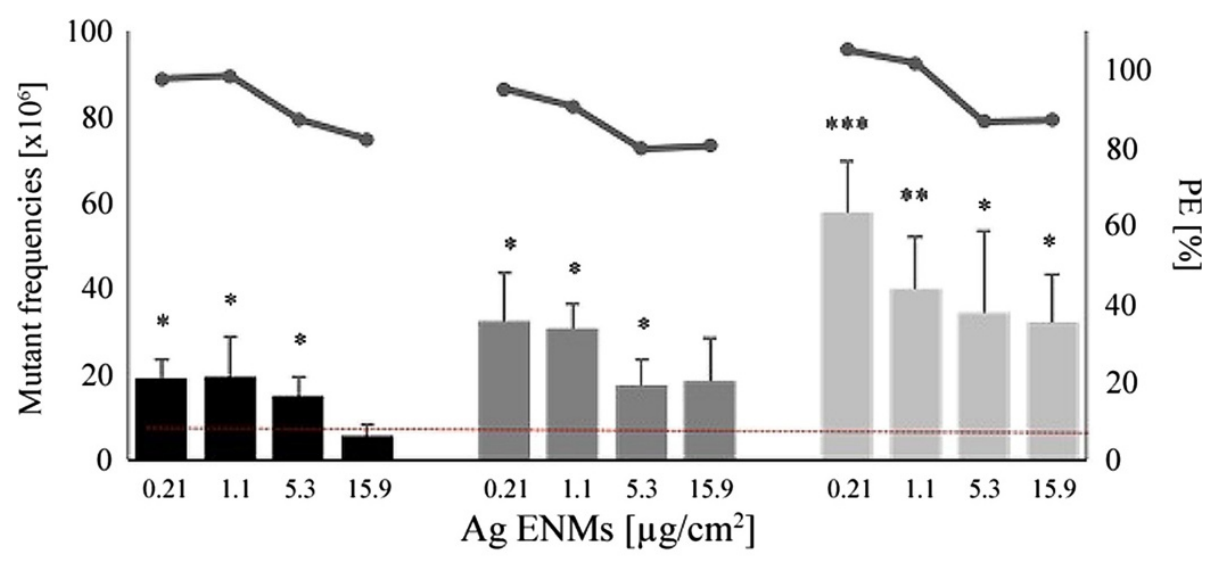

\section{Ag ENMs $50 \mathrm{~nm} \quad$ Ag ENMs $80 \mathrm{~nm} \quad$ Ag ENMs $200 \mathrm{~nm}$}

Figure 6 Effect of $24 \mathrm{~h}$ treatment with 50, 80 and $200 \mathrm{~nm}$ Ag ENMs (0.21-15.6 $\left.\mu \mathrm{g} / \mathrm{cm}^{2}\right)$ on induction of hprt gene mutations in V79-4 cells (bar graphs, left hand scale). The mutant frequencies $\left(\times 10^{6}\right)$ are expressed as the mean \pm SD of two independent experiments, with two independent harvests per experiment. Horizontal line shows hprt gene mutant frequency in untreated cells $(8.47 \pm 3.83)$. MMS $(0.03 \mu \mathrm{M}, 30 \mathrm{~min})$, a positive control gave $80.03 \pm 22.13 \mathrm{hprt}$ gene mutations. Significant difference from unexposed control $\left({ }^{*} p<0.05,{ }^{* *} p<0.01,{ }^{* * *} p<0,001\right)$. Cytotoxic effects - Plating efficiency (PE) (horizontal marker line, right hand scale) is expressed as the mean of two independent experiments. Results represent cytotoxicity relative to $100 \%$ of the negative control. Cytotoxicity of MMS has not been observed (PE $=97.99 \pm 6.14 \%$ ).

potential adverse health effects. Risk assessment strategies for ENMs require relevant in vitro toxicology research of new materials, with special attention given to the mechanisms of toxicity and the use of representative reference materials to correlate the toxic effect of ENMs with their specific physico-chemical properties. Investigations so far have shown that the toxic potential of ENMs is related to their physico-chemical properties, such as shape, size, charge, aggregation stage and chemical composition [35-40].

Several researchers reported that cytostatic, cytotoxic and genotoxic effects of Ag ENMs are mostly mediated via oxidative stress, e.g. via high production of reactive oxygen species (ROS) [41]. The induced oxidative stress may affect cell cycle, resulting in $\mathrm{G} 2 / \mathrm{M}$ phase arrest which leads to apoptosis and causes cell death [12]. The observed toxicity of $\mathrm{Ag}$ ENMs is thus the result of ENMs uptake and localised release of high concentrations of $\mathrm{Ag}$ ions inside the cells, known as the Trojan horse mechanism [42].

PE and RGA were selected to study proliferation and direct cytotoxic effects of Ag ENMs as well as cellular viability. The advantage of these tests in nanotoxicology is that there is no or little risk of interference between the assay and the ENMs $[23,43]$. We demonstrated that cytotoxic and cytostatic effects were observed after exposure to all ENMs tested, and that this response increased with the duration of the exposure and the ENM concentration. The strong positive effects from Ag ENMs $50 \mathrm{~nm}$ observed after the short $2 \mathrm{~h}$ exposure in the RGA assay is mostly related either to cell membrane damage (which can be repaired) or necrosis (cell dying) and thus it reflects several toxic effects. For the PE assay, any ENM taken up by the cells during the exposure remain in the cells, although gradual dilution of the ENM load occurs as a result of cell division as the ENMs are split between daughter cells [44]. Thus, differences in the $\mathrm{IC}_{50}$ values between the PE and RGA assays suggest that most of the initial (early time) damage can be repaired after the end of exposure, when the cells are further cultivated in ENM free medium and the initial ENM concentration is diluted over time due to cell division. Nevertheless, reduction of viable populations to lower than $60 \%$ was found at higher Ag ENM concentrations. No significant differences were found between 80 and $200 \mathrm{~nm} \mathrm{Ag} \mathrm{ENMs,} \mathrm{albeit} \mathrm{the} \mathrm{ENMs}$ numbers were lower here, and the trends observed also mirrored those of the $50 \mathrm{~nm}$ Ag ENMs.

Genotoxic effects of Ag ENMs have been extensively studied, and many researchers reported that Ag ENMs can induce different types of DNA damage, including strand breaks, DNA oxidation, bulky DNA adducts, formation of micronuclei and chromosome aberrations $[14,26,45]$. Genotoxicity testing in a regulatory perspective requires a battery of tests addressing these different genotoxic and mutagenic endpoints. The Comet assay is one of the most commonly used methods to study specific DNA lesions such as single and double strand breaks, oxidation, alkylation of DNA, cross links, and can be successfully applied in nanogenotoxicology $[23,46,47]$. According to recent literature, the toxic effect of ENMs may be coupled with ROS production. For this reason, we used a modified protocol including the incubation of nuclei 
embedded in gels with FPG to detect oxidised purines, predominantly 8 -oxo-guanine, one of the most pre-mutagenic lesions [48].

Previous studies reported a possible genotoxic potential of Ag ENMs, showing that Ag ENMs can induce DNA breaks and DNA oxidation. However, differences between nano- and microsized Ag ENMs were never taken fully into consideration.

Our results report significant increase of DNA damage after $2 \mathrm{~h}$ exposure to Ag ENMs $50 \mathrm{~nm}$. However, the two highest concentrations tested also substantially reduced the viable cell populations, which means that the higher level of DNA damage might be a result of potential apoptosis or necrosis rather than genotoxicity. Due to the high cytotoxicity and almost saturated level of strand breaks, a significant increase of oxidised purines was not found at these ENM concentrations. Slight but significant increases in DNA breaks were found in both 80 and $200 \mathrm{~nm} \mathrm{Ag}$ ENMs treated cells at both short $(2 \mathrm{~h})$ and long $(24 \mathrm{~h})$ exposure times, with no differences observed between the two ENM sizes. An increased level of DNA breaks was found mostly at the cytotoxic concentrations $\left(\geq 5.3 \mu \mathrm{g} / \mathrm{cm}^{2}\right)$.

On the other hand, an increased number of oxidised DNA lesions was observed in viable cell populations, which correlates with the fact that Ag ENMs have an impact on ROS production in cells. These results also demonstrate the importance of studying specific DNA lesions such as oxidised purines (the majority of these lesions are 8-oxo-guanins) that could be detected by FPG, or OGG1 glycosylases [48]. A decreasing level of DNA damage was observed between the 2 and $24 \mathrm{~h}$ exposures for cells treated with $50 \mathrm{~nm} \mathrm{Ag} \mathrm{ENMs.} \mathrm{This}$ could be due to removal of some parts of damaged cells during the washing step after exposure, be the result of the ENMs distribution between new generations of cells, or be a result of DNA repair and cellular recovery. In our previous nanotoxicology studies we investigated the potential for oxidized DNA lesions caused by Ag ENMs to be reduced by the presence of antioxidants. We used plant extract from Gentiana asclepiadea, rich in substances with high antioxidant abilities such as a swertiamarin, mangiferin and homoorientin $[14,49]$. DNA oxidation induced by Ag ENMs was efficiently diminished by these plants extracts. Additionally, we demonstrated that the presence of antioxidants significantly enhanced DNA repair. We measured levels of DNA lesions at different time points after exposing cells to Ag ENMs. Cells incubated with plant extract from Gentiana asclepiadea had significantly lower level of DNA damage compared to the control group, which proved that the presence of antioxidants can inhibit the harmful effects of Ag ENMs [49]. To investigate the mutagenic potential of Ag ENMs we applied the hprt gene mutation assay. In genotoxicity testing the most used assay for mutagenicity is the bacterial Ames test. However, this assay has serious limitations for ENM mutagenicity testing because of the size of bacteria (not much bigger than some ENMs), and due to the presence of the cell wall which results in limited or no uptake of ENMs as they cannot pass through the bacterial wall [30]. Tedser et al. did not find any mutagenic effect of PVP stabilized Ag ENMs with different sizes and shapes in Ames/Salmonella typhimurium assay [50]. Another two studies using the Ames test also reported no mutagenic effects of Ag ENMs [51,52] although these most likely show false negative results. The hprt gene mutation assay has clear advantages for testing of ENMs as it is based on a mammalian cell model that is closer to human physiology. To date, there are only a few publications on mammalian mutagenicity of ENMs published. Kim et al. applied the thymidine kinase $\left(t k^{+/-}\right)$gene mutation assay based on the mammalian L5178Y cell line, and reported no/slight but not significant increase of thymidine kinase mutants in cells treated by Ag ENMs [53]. However, it is difficult to interpret this study because of differences in the materials used, and the lack of detailed ENM characterization.

In the study reported herein, a high number of hprt mutants were observed, in viable cell populations, with all tested Ag ENMs. Interestingly, the number of mutants decreased with increasing ENM concentration. This might be due to larger genetic malformations being induced by higher ENM concentrations that consequently reduce cell viability of the mutant cells with the result that lower mutant frequency is observed. Wang et al. reported a 2.5 fold increase in the mutant frequency in WIL2-NS cells treated by ultrafine $\mathrm{TiO}_{2}$ ENMs, but the positive effect was only observed at the higher tested concentration [54]. Also diesel exhaust NMs and carbon black ENMs were shown to be mutagenic, significantly increasing the mutant frequency in FE-1Muta ${ }^{\mathrm{Tm}}$ mouse lung epithelial cells [55,56]. A similar reverse concentration response has been observed in a separate study performed in our lab using gold ENMs, and again is suggested to result from more extreme mutations occurring at higher concentrations resulting in lower mutant cell viability and thus lower observation of mutant frequency [Porredon C, El Yamani N, Lapuente J, López DR, Coloma $\mathrm{A}$, Borràs $\mathrm{M}$, Dusinska $\mathrm{M}$ : In vitro genotoxicity study of coated and uncoated gold nanoparticles evaluated by the Mammalian cell hprt gene mutation assay in Chinese hamster V79 cells. Manuscript in preparation].

Correlation of results from the Comet assay and the hprt gene mutations assay is challenging as these two tests measure different endpoints and require different cell types, cell seeding densities and exposure durations, leading to different ENM exposure regimes. In the Comet assay we measured several types of DNA damage, DNA 
strand breaks and oxidized DNA lesions that are considered as pre-mutagenic lesions. The Comet assay thus detects transient DNA lesions that can be repaired, or can result in mutations. Also, the outcomes might be affected by several other biological processes such as apoptosis or necrosis. With the Comet assay it is crucially important to measure DNA damage at non-cytotoxic or slightly cytotoxic ENM concentrations to ensure that the effect observed is not related to cytotoxicity. Compared to the Comet assay, the hprt gene mutation test detects permanent changes in the nucleotide sequence of the genetic material inherited or raised by incorrect nucleotide base pairing during replication or by erroneous repair. We performed the hprt mutation test following OECD guideline which recommend V79-4 cells (as A549 cells are not a suitable cellular model for this test). V79-4 cells have a shorter cell cycle $(12 \mathrm{~h})$ compared to A549 (24 h), and thus due to faster cell division, the total number of ENMs is diluted in V79-4 cells between new, daughter cells more rapidly which results in different concentrations during exposure compared to A549 cells.

ENMs can induce mutagenicity via direct or indirect mechanisms. Indirect mechanisms involve ROS production or inflammation [57]. Hackenber and Greulich demonstrated that Ag ENMs can stimulate release of inflammatory markers (IL-8 and IL-6) but only at non cytotoxic ENM concentrations. Additionally, they found that at cytotoxic and genotoxic concentrations of Ag ENMs, production of cytokines is inhibited [18,58]. This same phenomenon was observed at the size depended toxicity study of PVP stabilized Ag ENMs with nominal sizes 4, 20 and $70 \mathrm{~nm}$ [59]. Production of inflammatory markers in our study also decreased with increased concentrations of Ag ENMs, as already reported by Kermanizadeh et al. and by Mahl et al. using a panel of different ENMs [60,61]. However, we did not find significant differences between all three tested Ag ENMs, nor very significant concentration-responses, suggesting that this is not a sensitive marker for Ag ENMs. Although we did not study possible interference of PVP coated ENMs with ELISA, we found that PVP immobilized at ENM surfaces reduces protein binding, suggesting that the likelihood of such interference is low [33].

The significant differences between nano and nonnano sized Ag in both cytotoxicity and genotoxicity can be explained by the intercellular localisation and number of ENMs taken up by cells. Smaller ENMs were found close to chromatin (Ag ENMs $50 \mathrm{~nm}$ ) or mitochondria and nucleus (Ag ENMs $80 \mathrm{~nm}$ ). Smaller ENMs are also taken up faster and to a higher extent compared to micro sized (Ag ENM $200 \mathrm{~nm}$ ) materials. The lower uptake of $200 \mathrm{~nm} \mathrm{Ag} \mathrm{ENMs} \mathrm{compared} \mathrm{to} 50 \mathrm{~nm}$ ones is consistent with the lower particle numbers at constant mass and the lower efficiency of endocytotic receptors for larger entities. Recently, Varela et al. studied size-dependent uptake rates of fluorescently labelled carboxylated polystyrene ENMs (20, 40 and $100 \mathrm{~nm}$ ) in two different cell types (A549 and $1321 \mathrm{~N} 1$ human astrocytoma), keeping the number of ENMs per unit volume constant for all sizes [62]. They showed that $40 \mathrm{~nm}$ carboxylated polystyrene ENMs were internalized faster than $20 \mathrm{~nm}$ or $100 \mathrm{~nm}$ ENMs in both cell lines studied, suggesting that there is a privileged size gap in which the internalization of ENMs is higher. Interestingly, previous TEM studies, using both polystyrene and silica ENMs have not shown any evidence of internalised ENMs existing outside of endosomal, lysososal or multi-lamellar structures nor was there any evidence of cellular damage in response to the presence of the ENMs such as that observed with the Ag ENMs $50 \mathrm{~nm}$ in Figure 2.1C [63,44].

Previous studies investigated different mechanisms involved in Ag ENMs toxicity and showed that toxicity of Ag ENMs is size dependent and such size dependence can be also correlated with release of ions [27]. Smaller Ag ENMs released more ions than bigger ENMs. However, the ion fraction released during exposure did not have an impact on cell toxicity [27]. Among our extensive ENM characterization, XPS data demonstrated that all of the surface atoms were in the $\mathrm{Ag}^{0}$ state, confirming the absence of $\mathrm{Ag}$ ions in the Ag ENMs solution in contrast with many published studies $[10,11,14,15,18,51,58]$. In an additional study (published separately) we investigated the kinetics of Ag ENMs dissolution during storage, and found no significant changes in Ag ENMs physicochemical properties, including dissolution or aggregation/ agglomeration over 6 months in Ag ENMs with neutral charge [Izak-Nau E, Huk A, Reidy B, Uggerud H, Vadset M, Eiden S, Voetz M, Duschl A, Dušinska M, Lynch I: Impact of Storage Conditions and Storage Time on Silver Nanoparticle Physicochemcial Proper ties and Implications for Biological Effects. Manuscript in preparation]. This finding was also confirmed by Kittler et al. [32]. However, Ag ENMs can release Ag ions during exposure in cell culture medium, although literature suggests that most of the $\mathrm{Ag}$ ions are bound with chlorine ions present in medium and precipitate as $\mathrm{AgCl}$ salt [64]. Several studies show that the level of free ion fractions is between 6-20\% of the applied concentration of Ag ENMs $[27,33,40,65,66]$ and this concentration is too low to cause toxic effect. Additionally, experiments with the ultracentrifuged ion fraction obtained from PVP stabilized Ag ENMs (similar to our ENMs) have shown no effect on cell viability or genotoxicity, suggested limited dissolution of the PVP-capped Ag ENM over the relevant timeframe $[24,27,40]$.

Comparison between the observed toxicity of nano and micro scale of Ag ENMs was studied by Park et al., who reported strong differences between $20 \mathrm{~nm}$ and 
$113 \mathrm{~nm}$ Ag ENMs in both cytotoxicity and immune regulation assays [67]. Our study shows that Ag ENMs $50 \mathrm{~nm}$ are more cytotoxic and genotoxic than the larger materials tested, mostly because of the higher surface area and higher number of ENMs at constant mass relative to the 80 and $200 \mathrm{~nm}$ Ag ENMs. However, of the Ag ENMs studied, the $200 \mathrm{~nm}$ Ag ENMs which had the smallest surface area and the lowest number of ENMs per volume were observed to have the strongest impact on induction of mutations (Additional file 4: Figures S11 and S12). The results from the hprt gene mutation assay suggest that the mode of action of genotoxicity of Ag ENMs can go via several simultaneous mechanisms, with the final impact being dependent on ENM size, concentration, type of damage induced and whether the damage can be repaired.

\section{Conclusion}

The main goal of this study was to assess whether there is a correlation between the size of Ag ENMs and their toxic potential. We were interested to see if ENMs with the same shape, charge and chemical composition (including the stabilizing coating) but with different sizes resulted in similar toxicity responses in mammalian cells. Our results show that it cannot be generalized that $\mathrm{Ag}$ in nano form is always more toxic than its micro form with the same chemical composition and all other factors being equal, as suggested by Karlsson et al. [68]. In our study, we observed strong cytotoxic and genotoxic effects of $\mathrm{Ag}$ ENMs $50 \mathrm{~nm}$, but from the tested materials Ag ENMs $200 \mathrm{~nm}$ had the most mutagenic potential. Our study demonstrates that Ag ENMs can induce DNA damage via more than one mechanism; directly by contact with chromatin or DNA [12], as also shown in TEM (Figure 2.1B and $2.2 \mathrm{C}$ ), or indirectly by ROS production which was indicated by DNA oxidation. Our results also show that expression of ENM concentrations as number of ENMs or in terms of surface area is more representative for evaluation of toxicity of different sized ENMs than using the usual mass units.

\section{Additional files}

Additional file 1: Figure S1. Detailed characterization of Ag ENMs $50 \mathrm{~nm}$.

Additional file 2: Figure S2. Detailed characterization of Ag ENMs $80 \mathrm{~nm}$.

Additional file 3: Figure S3. Detailed characterization of Ag ENMs $200 \mathrm{~nm}$.

Additional file 4: Figure S4. Light microscopy (100x) of A549 cells incubated with 50, 80, $200 \mathrm{~nm}$ Ag ENMs (concentration $21.2 \mu \mathrm{g} / \mathrm{cm}^{2}$ ) for 24 h. A: Negative control, B: Cells treated with Ag ENMs $50 \mathrm{~nm}$; C: cells treated with Ag ENMs $80 \mathrm{~nm}$; D: cells treated with Ag ENMs $200 \mathrm{~nm}$. Figure S5. Cytotoxic effects of 50, 80 and $200 \mathrm{~nm}$ Ag ENMs on A549 cells measured as Relative growth activity (RGA) and Plating efficiency (PE). Concentrations of Ag ENMs expressed as ENMs $\mathrm{cm}^{2} / \mathrm{cm}^{2}$.

Figure S6. Cytotoxic effects of 50, 80 and $200 \mathrm{~nm}$ Ag ENMs on A549 cells measured as Relative growth activity (RGA) and Plating efficiency (PE). Concentrations of Ag ENMs expressed as ENMs $/ \mathrm{cm}^{2}$. Figure S7.
Level of DNA damage - strand breaks and oxidised DNA lesions expressed as NET FPG in A549 cells exposed to different concentrations of Ag ENMs. Concentrations of Ag ENMs expressed as ENMs $\mathrm{cm}^{2} / \mathrm{cm}^{2}$. Figure S8. Level of DNA damage - strand breaks and oxidised DNA lesions expressed as NET FPG in A549 cells exposed to different concentrations of Ag ENMs. Concentrations of Ag ENMs expressed as ENMs $/ \mathrm{cm}^{2}$. Figure S9. Induction of IL-8 and MCP-1 in A549 cells exposed to Ag ENMs 50, 80 and $200 \mathrm{~nm}$. Concentrations of Ag ENMs expressed as ENMs $\mathrm{cm}^{2} / \mathrm{cm}^{2}$. Figure S10. Induction of IL-8 and MCP-1 in A549 cells exposed to Ag ENMs 50, 80 and $200 \mathrm{~nm}$. Concentrations of Ag ENMs expressed as ENMs $/ \mathrm{cm}^{2}$. Figure S11. Effect of $24 \mathrm{~h}$ treatment with 50, 80 and $200 \mathrm{~nm}$ Ag ENMs on induction of hprt gene mutations in V79-4 cells. Concentrations of Ag ENMs expressed as ENMs $\mathrm{cm}^{2} / \mathrm{cm}^{2}$. Figures $\mathbf{S 1 2}$. Effect of $24 \mathrm{~h}$ treatment with 50, 80 and $200 \mathrm{~nm} \mathrm{Ag} \mathrm{ENMs} \mathrm{on} \mathrm{induction}$ of hprt gene mutations in V79-4 cells. Concentrations of Ag ENMs expressed as ENMs/ $\mathrm{cm}^{2}$.

\section{Abbreviations}

A549: Human lung carcinoma epithelial cells; AC: Analytical centrifugation; BET: Brauner-Emmett-Teller; DLS: Dynamic Light Scattering; ELISA: Enzyme linked immunosorbent assay; ENMs: Engineered nanomaterials; FPG: Formamidopyrymidine DNA glycosylase; $I_{50}$ : Half maximal inhibitory concentration; OECD: Organization for Economic Co-operation and Development; PE: Plaiting efficiency; PVP: Polyvinylpyrrolidone; RGA: Relative Growth Activity; SEM: Scanning electron microscopy; SBs: Strand breaks; TEM: Transmission electron microscopy; ToR SIMS: Time-of-flight secondary ion mass spectrometry IV; V79-4: Chinese hamster lung fibroblast cells; XPS: X-ray photoelectron spectroscopy; XRD: X-ray diffraction.

\section{Competing interests}

The authors declare that they have no competing interests.

\section{Authors' contributions}

AH performed the cell proliferation, cytotoxicity, immunotoxicity, genotoxicity and mutagenicity experiments. She was also heavily involved in the preparation, writing and revision of the manuscript. EIN synthesised Ag ENMs, performed the Ag ENMs characterization and wrote the sections about the ENMs synthesis and characterization. BR performed uptake and subcellular localization study and wrote the part about uptake. MB was involved in the experimental design of immunotoxicity study and critically revised the manuscript. IL obtained funding for the project, designed the uptake and localization studies and supported their interpretation, and critically revised the manuscript. AD obtained funding for the project and critically revised the manuscript. MD was involved in the experimental design of the cell proliferation, cytotoxicity, genotoxicity and mutagenicity and the coordination of the study. She obtained funding for the project and she was also heavily involved in the preparation and revision of the manuscript. All authors read and approved the final manuscript.

\section{Acknowledgement}

This research was supported by the EU 7th framework program, Marie Curie Actions, Network for Initial Training NanoTOES (PITN-GA-2010-264506), EC FP7 QualityNano [INFRA-2010-1.131], contract No: 214547-2, and EC FP7 NANoREG, [NMP.2012.1.3-3] contract No: 310584. We thank Mr. Michal Zagrodzki for help with graphic design.

\section{Author details}

'Department of Environmental Chemistry, Health Effects Laboratory, NILU, Instituttveien 18, 2007 Kjeller, Norway. ${ }^{2}$ Department of Molecular Biology, University of Salzburg, Salzburg, Austria. ${ }^{3}$ Bayer Technology Services GmbH, Leverkusen, Germany. ${ }^{4}$ Centre for BioNano Interactions, School of Chemistry and Chemical Biology University College Dublin, Belfield, Dublin 4, Ireland. ${ }^{5}$ School of Geography, Earth \& Environmental Sciences, University of Birmingham, Edgbaston, B15 2TT, Birmingham, UK.

Received: 9 May 2014 Accepted: 10 November 2014

Published online: 03 December 2014 


\section{References}

1. Emamifar A, Kadivar M, Shahedi M, Soleimanian-Zad S: Evaluation of nanocomposite packaging containing $\mathrm{Ag}$ and $\mathrm{ZnO}$ on shelf life of fresh orange juice. Innovat Food Sci Emerg Tech 2010, 11:742-748.

2. Dastjerdi R, Montazer M: A review on the application of inorganic nano-structured materials in the modification of textiles: Focus on anti-microbial properties. Colloids and Surf B: Biointerfaces 2010, 79:5-18.

3. Khot LR, Sankaran S, Maja JM, Ehsani R, Schuster EW: Applications of nanomaterials in agricultural production and crop protection: A review. Crop Prot 2012, 35:64-70.

4. Li Q, Mahendra S, Lyon DY, Brunet L, Liga MV, Li D, Alvarez PJJ: Antimicrobial nanomaterials for water disinfection and microbial control. Potential applications and implications. Water Res 2008, 42:4591-4602.

5. Brar SK, Verma M, Tyagi RD, Surampalli RY: Engineered nanoparticles in wastewater and wastewater sludge - Evidence and impacts. Waste Manag 2010, 30:504-520.

6. Sotiriou GA, Pratsinis SE: Engineering nanosilver as an antibacterial, biosensor and bioimaging material. Curr Opin in Chem Eng 2011, 1:3-10.

7. Chaloupka K, Malam Y, Seifalian AM: Nanosilver as a new generation of nanoproduct in biomedical applications. Trends Biotechnol 2010, 28:580-588.

8. Hamouda IM: Current perspectives of nanoparticles in medical and dental biomaterials. J Biomed Res 2010, 26:143-151.

9. Nowack B, Krug HF, Height M: 120 Years of Nanosilver History: Implication for Policy Makers. Environ Sci Technol 2011, 45:1177-1183.

10. Piao MJ, Kang KA, Lee IK, Kim HS, Kim S, Choi JY, Choi J, Hyuna JW: Silver nanoparticles induce oxidative cell damage in human liver cells through inhibition of reduced glutathione and induction of mitochondria-involved apoptosis. Tox Lett 2011, 201:92-100.

11. Asare N, Instanes C, Sandberg WJ, Refsnes M, Schwarze P, Kruszewski M, Brunborg G: Cytotoxic and genotoxic effects of silver nanoparticles in testicular cells. Toxicology 2011, 291:65-72.

12. AshaRani PV, Low Kah Mun G, Hande MP, Valiyaveettil S: Low Kah Mun G, Hande MP, Valiyaveettil S: Cytotoxicity and Genotoxicity of Silver Nanoparticles in Human Cells. ACS Nano 2008, 3:279-290.

13. Flowera NAL, Brabua B, Revathy M, Gopalakrishnana C, Raja SVK, Murugan SS, Kumaravel TS: Characterization of synthesized silver nanoparticles and assessment of its genotoxicity potentials using the alkaline comet assay. Mutat Res 2012, 742:61-65.

14. Hudecová A, Kusznierewicz B, Rundén-Pran E, Magdolenová Z, Hasplová K, Rinna A, Fjellsbø LM, Kruszewski M, Lankoff A, Sandberg WJ, Refsnes M, Skuland T, Schwarze P, Brunborg G, Biøras M, Collins A, Miadoková E, Gálová E, Dusinská M: Silver nanoparticles induce premutagenic DNA oxidation that can be prevented by phytochemicals from Gentiana asclepiadea. Mutagenesis 2012, 6:759-769.

15. Miura N, Shinohara Y: Cytotoxic effect and apoptosis induction by silver nanoparticles in HeLa cells. Biochem Biophys Res Commun 2010, 390:733-737.

16. Kim YS, Kim JS, Cho HS, Rha DS, Kim JM, Park JD, Choi BS, Lim R, Chang HK, Chung YH, Kwon IH, Jeong J, Han BS, Yu IJ: Twenty-eight-day oral toxicity, genotoxicity, and gender-related tissue distribution of silver nanoparticles in Sprague-Dawley rats. Inhal Toxicol 2008, 20:575-583.

17. Lu W, Senapati D, Wang S, Tovmachenko O, Singh AK, Yu H, Ray PC: Effect of surface coating on the toxicity of silver nanomaterials on human skin keratinocytes. Chem Phys Lett 2010, 487:92-96.

18. Greulich C, Diendorf J, Geßmann J, Simon T, Habijan T, Eggeler G, Schildhauer TA, Epple M, Köller M: Cell type-specific responses of peripheral blood mononuclear cells to silver nanoparticles. Acta Biomat 2011, 7:3505-3514.

19. Zouhir E, Allouni ZE, Cimpan MR, Høl PJ, Skodvin T, Gjerdet NR: Agglomeration and sedimentation of $\mathrm{TiO} 2$ nanoparticles in cell culture medium. Colloids Surf B Biointerfaces 2009, 68:83-87.

20. Petri-Fink A, Steitz B, Finka A, Salaklang J, Hofmann H: Effect of cell media on polymer coated superparamagnetic iron oxide nanoparticles (SPIONs): Colloidal stability, cytotoxicity, and cellular uptake studies. Eur J Pharm Biopharm 2008, 68:129-137.

21. Lesniak A, Campbell A, Monopoli M, Lynch I, Salvati A, Dawson KA: Serum heat inactivation affects protein corona composition and nanoparticle uptake. Biomaterials 2010, 31:9511-9518.

22. Dawson KA, Anguissola S, Lynch I: The need for in situ characterisation in nanosafety assessment: funded transnational access via the QNano research infrastructure. Nanotoxicology 2013, 7:346-349.
23. Dusinska M, Magdolenova Z, Fjellsbø LM: Toxicological aspects for nanomaterial in humans. Methods Mol Biol 2013, 948:1-12.

24. Beer C, Foldbjerg R, Hayashi Y, Sutherland DS, Autrup H: Toxicity of silver nanoparticles - nanoparticle or silver ion? Toxicol Lett 2012, 5:286-292.

25. Wang H, Qiao X, Chen J, Wang X, Ding S: Mechanisms of PVP in the preparation of silver nanoparticles. Mat Chem Phys 2005, 94:449-453.

26. Foldbjerg $\mathrm{R}$, Dang DA, Autrup $\mathrm{H}$ : Cytotoxicity and genotoxicity of silver nanoparticles in the human lung cancer cell line, A549. Arch Tox 2011, 85:743-750.

27. Gliga AR, Skoglund S, Wallinder IO, Fadeel B, Karlsson HL: Size-dependent cytotoxicity of silver nanoparticles in human lung cells: the role of cellular uptake, agglomeration and Ag release. Part Fibre Toxicol 2014, 11:11-28. doi:10.1186/1743-8977-11-11.

28. Liu W, Wu Y, Wang C, Li HC, Wang T, Liao CY, Cui L, Zhou QF, Yan B, Jiang GB: Impact of silver nanoparticles on human cells:effect of particle size. Nanotoxicology 2010, 4:319-330.

29. Sung JH, Jun Ho J, Jung Duck P, Jin Uk Y, Dae Sung K, Ki Soo J, Moon Yong S, Jayoung J, Beom Seok H, Jeong Hee H, Yong Hyun C, Hee Kyung C, Ji Hyun L, Myung Haing C, Kelman BJ, II Je Y: Subchronic Inhalation Toxicity of Silver Nanoparticles. Tox Sci 2009, 108:452-461.

30. Doak SH, Manshian B, Jenkins GJ, Singh N: In vitro genotoxicity testing strategy for nanomaterials and the adaptation of current OECD guidelines. Mutat Res 2012, 14:104-111.

31. Harris G, Palosaari T, Magdolenova Z, Mennecozzi M, Gineste JM, Saavedra L Milcamps A, Huk A, Collins AR, Dusinska M, Whelan M: Iron oxide nanoparticle toxicity testing using high throughput analysis and high content imaging. Nanotoxicology 2013. doi:10.3109/17435390.2013.816797. PubMed PMID: 23859183.

32. Kittler S, Greulich C, Diendorf J, Keoller M, Epple M: Toxicity of silver nanoparticles increases during storage because of slow dissolution under release of silver ions. Chem Mater 2010, 22:4548-4554.

33. Wang $X$, Ji Z, Chang CH, Zhang H, Wang M, Liao YP, Lin S, Meng H, Li R, Sun B, Winkle LV, PENMinkerton KE, Zink JI, Xia T, Nel AE: Use of coated silver nanoparticles to understand the relationship of particle dissolution and bioavailability to cell and lung toxicological potential. Small 2014, 10:385-398

34. Izak-Nau E, Voetz M, Eiden S, Duschl A, Puntes VF: Altered characteristics of silica nanoparticles in bovine and human serum: the importance of nanomaterial characterization prior to its toxicocal evaluation. Part Fimb Toxicol 2013, 10:56-68.

35. Xiong Y, Brunson M, Huh J, Huang A, Coster A, Wendt K, Fay J, Qin D: The role of surface chemistry on the toxicity of ag nanoparticles. Small 2013, 15:2628-2638.

36. He C, Hu Y, Yin L, Tang C, Yin C: Effects of particle size and surface charge on cellular uptake and biodistribution of polymeric nanoparticles. Biomaterials 2010, 31:3657-3666.

37. Sohaebuddin SK, Thevenot PT, Baker D, Eaton JW, Tang L: Nanomaterial cytotoxicity is composition, size, and cell type dependent. Part Fibre Toxicol 2010, 7:22-39.

38. Magdolenova Z, Drlickova M, Henjum K, Rundén-Pran E, Tulinska J, Bilanicova D, Pojana G, Kazimirova A, Barancokova M, Kuricova M, Liskova A, Staruchova M, Ciampor F, Vavra I, Lorenzo Y, Collins A, Rinna A, Fjellsbø L, Volkovova K, Marcomini A, Amiry-Moghaddam M, Dusinska M: Coating-dependent induction of cytotoxicity and genotoxicity of iron oxide nanoparticles. Nanotox 2013. doi:10.3109/17435390.2013.847505. PMID: 24228750.

39. Magdolenova Z, Bilaničová D, Pojana G, Fjellsbø LM, Hudecova A, Hasplova K, Marcomini A, Dusinska M: Impact of agglomeration and different dispersions of titanium dioxide nanoparticles on the human related in vitro cytotoxicity and genotoxicity. J Environ Monit 2012, 2:455-464.

40. Stoehr LC, Gonzalez E, Stampfl A, Casals E, Duschl A, Puntes V, Oostingh GJ: Shape matters: effects of silver nanospheres and wires on human alveolar epithelial cells. Part Fibre Toxicol 2011, 8:36-51.

41. Limbach LK, Wick P, Manser P, Grass RN, Bruinink A, Stark WJ: Exposure of engineered nanoparticles to human lung epithelial cells: influence of chemical composition and catalytic activity on oxidative stress. Environ Sci Technol 2008, 41:4158-4163.

42. Park EJ, Yi J, Kim Y, Choi K, Park K: Silver nanoparticles induce cytotoxicity by a Trojan-horse type mechanism. Toxicol Vitro 2010, 3:872-878.

43. Guadagnini R, Halamoda Kenzaoui B, Cartwright L, Pojana G, Magdolenova Z, Bilanicova D, Saunders M, Juillerat L, Marcomini A, Huk A, Dusinska M, 
Fjellsbø LM, Marano F, Boland S: Toxicity screenings of nanomaterials: challenges due to interference with assay processes and components of classic in vitro tests. Nanotoxicology 2013. doi:10.3109/17435390.2013 829590. PMID:23889211.

44. Salvati A, Aberg C, dos Santos T, Varela J, Pinto P, Lynch I, Dawson KA: Experimental and theoretical comparison of intracellular import of polymeric nanoparticles and small molecules: toward models of uptake kinetics. Nanomedicine 2011, 7:818-826.

45. Babu K, Deepa M, Shankar SG, Rai S: Effect of Nano-Silver on Cell Division and Mitotic Chromosomes: A Prefatory Siren. Internet J Nanotech 2008, 2:2-5.

46. Magdolenova Z, Lorenzo Y, Collins A, Dusinska M: Can standard genotoxicity tests be applied to nanoparticles? J Toxicol Environ Health $A$ 2012, 75:800-806.

47. Collins AR, Dusinska M, Gedik C, Stetina R: Oxidative damage to DNA; do we have a reliable biomarker? Environ Health Perspect 1996, 104:465-469

48. Collins AR, Dusinska M: Oxidation of cellular DNA measured with the comet assay. Methods Mol Biol 2002, 186:147-159.

49. Hudecová A, Kusznierewicz B, Hašplová K, Huk A, Magdolenová Z, Miadoková E, Gálová E, Dušinská M: Gentiana asclepiadea exerts antioxidant activity and enhances DNA repair of hydrogen peroxideand silver nanoparticles-induced DNA damage. Food Chem Toxicol 2012, 50:3352-3359.

50. Tedsree K, Tiyawat W, Ketaram K, Phetlert C: Synthesis and mutagenicity of silver nanoparticles with different sizes and shapes. Pure Appl Chem Int Conf 2013. PACCON 2013. http://paccon2013.sci.buu.ac.th/sites/default/files/ uploaded_files/user1/Full_Abstract_complete.pdf.

51. Kim HR, Park YJ, Shin Da Y, Oh SM, Chung KH: Appropriate in vitro methods for genotoxicity testing of silver nanoparticles. Environ Health Toxicol 2013. doi:10.5620/eht.2013.28.e2013003. Article ID: e2013003.

52. Li Y, Chen DH, Yan J, Chen Y, Mittelstaedt RA, Zhang Y, Biris AS, Heflich RH Chen T: Genotoxicity of silver nanoparticles evaluated using the AmesTest and in vitro micronucleus assay. Mutat Res 2012, 745:4-10.

53. Kim JY, Yang Sl, Ryu JC: Cytotoxicity and genotoxicity of nanosilver in mammalian cell lines. Mol Cell Toxicol 2010, 6:119-125.

54. Wang JJ, Sanderson BJ, Wang H: Cyto- and genotoxicity of ultrafine TiO2 particles in cultured human lymphoblastoid cells. Mutat Res 2007, 628:99-106.

55. Jacobsen NR, Saber AT, White P, Møller P, Pojana G, Vogel U, Loft S, Gingerich J, Soper L, Douglas GR, Wallin H: Increased mutant frequency by carbon black, but not quartz, in the lacZ and cll transgenes of muta mouse lung epithelial cells. Environ Mol Mutagen 2007, 48:451-461.

56. Jacobsen NR, Møller P, Cohn CA, Loft S, Vogel U, Wallin H: Diesel exhaust particles are mutagenic in FE1-MutaMouse lung epithelial cells. Mutat Res 2008, 641:54-57.

57. Magdolenova Z, Collins A, Kumar A, Dhawan A, Stone V, Dusinska M: Mechanisms of genotoxicity. A review of in vitro and in vivo studies with engineered nanoparticles. Nanotoxicology 2014, 8:233-7858.

58. Hackenberg S, Scherzed A, Kessler M, Hummel S, Technau A, Froelich K, Ginzkey C, Koehler C, Hagen R, Kleinsasse N: Silver nanoparticles: Evaluation of DNA damage, toxicity and functional impairment in human mesenchymal stem cells. Toxicol Lett 2011, 201:27-33.

59. Park J, Lim DH, Lim HJ, Kwon T, Choi J, Jeong S, Choi IH, Cheon J: Size dependent macrophage responses and toxicological effects of $\mathrm{Ag}$ nanoparticles. Chem Commun 2011, 47:4382-4384.

60. Kermanizadeh A, Gaiser BK, Hutchison GR, Stone V: An in vitro liver model-assessing oxidative stress and genotoxicity following exposure of hepatocytes to a panel of engineered nanomaterials. Part Fibre Toxicol 2012, 19:9-28

61. Mahl D, Diendorf J, Ristig S, Greulich C, Li Z, Farle M, Ko M, Koller M, Epple M: Silver, gold, and alloyed silver-gold nanoparticles: characterization and comparative cell-biologic action. J Nanopart Res 2012, 14:1153-1166

62. Varela JA, Bexiga MG, Aberg C, Simpson JC, Dawson KA: Quantifying size-dependent interactions between fluorescently labeled polystyrene nanoparticles and mammalian cells. J Nanobiot 2012, 10:39-45.

63. Shapero K, Fenaroli F, Lynch I, Cottell DC, Salvati A, Dawson KA: Time and space resolved uptake study of silica nanoparticles by human cells. Mol Biosyst 2011, 7:371-378.
64. Reidy B, Haase A, Luch A, Dawson KA, Lynch I: Mechanisms of Silver Nanoparticle Release Transformation And Toxicity: A Critical Review of Current Knowledge and Recommendations for Future Studies and Applications. Materials 2013, 6:2295-2350.

65. Cronholm P, Karlsson HL, Hedberg J, Lowe TA, Winnberg L, Elinn K, Wallinder IO, Möller L: Intracellular uptake and toxicity of Ag and CuO nanoparticles: a comparison between nanoparticles and their corresponding metal ions. Small 2013, 9:970-982.

66. Bondarenko O, Ivask A, Käkinen A, Kurvet I, Kahru A: Particle-cell contact enhances antibacterial activity of silver nanoparticles. PLoS One 2013, 8:e64060.

67. Park MVDZ, Neigh AM, Vermeulen JP, Fonteyne LJ, Verharen HW, Briedé JJ, Loveren $\mathrm{H}$, Jong W: The effect of particle size on the cytotoxicity, inflammation, developmental toxicity and genotoxicity of silver nanoparticles. Biomaterials 2011, 32:9810-9817.

68. Karlsson HL, Gustafsson J, Cronholm P, Möller L: Size-dependent toxicity of metal oxide particles a comparison between nano- and micrometer size. Toxicol Lett 2009, 2:112-118.

doi:10.1186/s12989-014-0065-1

Cite this article as: Huk et al:: Is the toxic potential of nanosilver dependent on its size? Particle and Fibre Toxicology 2014 11:65.

\section{Submit your next manuscript to BioMed Central and take full advantage of:}

- Convenient online submission

- Thorough peer review

- No space constraints or color figure charges

- Immediate publication on acceptance

- Inclusion in PubMed, CAS, Scopus and Google Scholar

- Research which is freely available for redistribution

Submit your manuscript at www.biomedcentral.com/submit
( Biomed Central 